\title{
Surprising salmonid response to water diversion at four run-of-river hydroelectric projects in British Columbia
}

\author{
M.D. Hocking, S.G. Faulkner, K. Akaoka, A. Harwood, T. Hatfield, and F.J.A. Lewis
}

\begin{abstract}
Run-of-river (RoR) hydroelectric power provides renewable energy with potentially less impact on fish habitat productivity than large, reservoir-storage hydroelectric projects. This is the first empirical study of resident fish response to water diversion at RoR projects in BC, where the abundance of rainbow trout (Oncorhynchus mykiss) was monitored in four small streams using a before-after control-impact design. Although flows in the diversion reaches of these projects were reduced by $63 \%$ to $70 \%$, the total biomass of rainbow trout increased from $35 \%$ to $157 \%$ across the streams compared with the "before period" and "control reaches". The response to water diversion differed among age classes: adult biomass increased with reduced flows in the growing season; juvenile biomass increased with reduced flows in the winter, higher stream conductivity, and increased flows in late summer; and fry biomass increased with higher stream conductivity and temperatures. One novel way to contextualize these shifts in resident salmonid productivity and differential growth and (or) survival by age class is via a size-density approach, which we use here to demonstrate how the carrying capacity of a stream for rainbow trout is affected by water diversion.
\end{abstract}

Résumé : Les centrales électriques au fil de l'eau fournissent de l'électricité renouvelable aux impacts potentiellement moindres sur la productivité des habitats des poissons que les grands projets hydroélectriques avec stockage en réservoir. Nous présentons la première étude empirique de la réaction de poissons résidents au détournement d'eau aux sites de projets au fil de l'eau en Colombie-Britannique, dans le cadre de laquelle l'abondance des truites arc-en-ciel (Oncorhynchus mykiss) dans quatre petits cours d'eau a été surveillée en utilisant un schéma avant-après témoin-impact. Bien que des réductions de 63 à 70 \% des débits aient été observées dans les tronçons de détournement de ces projets, la biomasse totale de truites arc-en-ciel a connu des augmentations de 35 à 157 \% dans les différents cours d'eau par rapport à la période " avant » et aux tronçons témoins. La réaction au détournement d'eau dépend de la classe d'âge, comme suit : la biomasse d'adultes a augmenté parallèlement à la réduction des débits durant la période de croissance, la biomasse de juvéniles a augmenté parallèlement à la réduction des débits hivernaux, à l'augmentation de la conductivité des cours d'eau et à l'augmentation des débits à la fin de l'été, et la biomasse de fretin a augmenté parallèlement à l'augmentation de la conductivité et de la température des cours d'eau. Une nouvelle manière de mettre en contexte ces changements de la productivité de salmonidés résidents et de leur croissance différentielle et/ou leur survie en fonction de la classe d'âge est par une approche basée sur la densité des tailles, que nous utilisons pour démontrer l'incidence du détournement d'eau sur la capacité biotique d'un cours d'eau en ce qui a trait aux truites arc-en-ciel. [Traduit par la Rédaction]

\section{Introduction}

As demand for water and hydroelectric power increases, resource managers need to understand how alteration of the natural flow regime affects the sustainability and productivity of river ecosystems (Power 1995; Poff et al. 1997; Poff and Zimmerman 2010) to balance hydroelectric power generation and maintenance of aquatic ecosystem services. Despite the potential advantages in limiting greenhouse gas emissions, hydroelectric projects can have harmful environmental effects, particularly where they include high-head dams that impound large reservoirs that alter physical and chemical habitats both upstream and downstream of the dam, leading to substantial impacts on stream ecology (Ligon et al. 1995; Rosenberg et al. 1997; Nilsson et al. 2005), especially fish such as salmonids (Baxter 1977; Murchie et al. 2008; Korman et al. 2011). These drawbacks and the emergence of lower cost renewable technologies with even lower emissions (Sims et al. 2003; Greenblatt et al. 2017), have led to criticism of hydroelectric energy as a sustainable form of renewable energy (Ansar et al. 2014), shifting development towards smaller-scale hydropower production options such as "run-of-river" (RoR) that may have less of an ecological impact on salmonid fishes and key ecosystem services (Anderson et al. 2015; Gibeau et al. 2017).

A typical RoR hydroelectric project generates $<25$ MW (Abbasi and Abbasi 2011) by impounding a small headpond, conveying water through a penstock tunnel for several kilometers around a 'diversion reach' (or bypass reach) to a powerhouse, and then returning the diverted flow to the channel via a tailrace (Anderson et al. 2015; Bilotta et al. 2016). RoR diversion reaches are typically $<5 \mathrm{~km}$ long, but the flows within are substantially reduced, typically to $10 \%$ or less of the natural mean annual discharge (MAD).

Received 6 July 2020. Accepted 6 March 2021.

M.D. Hocking.* Ecofish Research Ltd., 600 Comox Rd., Courtenay, BC V9W 2X9, Canada; School of Environmental Studies, University of Victoria, David Turpin Building, B243, Victoria, BC, Canada.

S.G. Faulkner, ${ }^{*}$ K. Akaoka, A. Harwood, T. Hatfield, and F.J.A. Lewis. Ecofish Research Ltd., 600 Comox Rd., Courtenay, BC V9W 2X9, Canada.

Corresponding author: M.D. Hocking (email: mhocking@ecofishresearch.com).

${ }^{*}$ Co-first authors.

() 2021 The Author(s). This work is licensed under a Creative Commons Attribution 4.0 International License (CC BY 4.0), which permits unrestricted use, distribution, and reproduction in any medium, provided the original author(s) and source are credited. 
A natural flow regime remains in the reach downstream of the powerhouse, because flows released from the powerhouse restore the diverted flows to the river channel. Few studies have documented the effects of the resulting flow regime in diversion reaches of RoR projects, despite the importance of the natural flow regime in maintaining key ecological functions that support fish populations (Poff et al. 1997)

The effects of RoR projects have been relatively little studied, and monitoring is required to fill this data gap in jurisdictions such as British Columbia (BC) where RoR projects have expanded (Lewis et al. 2013; Gibeau et al. 2017; Couto and Olden 2018). Research in other jurisdictions have shown decreases in fish biomass and shifts in fish communities as a result of the reduced water depth and velocity in diversion reaches (e.g., Kubečka et al. 1997; Habit et al. 2007; Gouraud et al. 2008; Ovidio et al. 2008; Sabaton et al. 2008; Bilotta et al. 2016). Research related to salmonids has indicated potential impacts from RoR associated with flow reduction and flow fluctuations, as well as from the presence of low-head dams that can impede migration or cause entrainment (reviewed in Gibeau et al. 2017).

In this study, we present the assessment and long-term monitoring results of salmonid response to water diversion at four RoR projects in southwestern BC, which to our knowledge is the first study to present monitoring data from such projects in Canada. The biomass of resident rainbow trout (Oncorhynchus mykiss) and environmental factors known to affect the productivity of fish habitats in streams (flow, temperature, water quality, and invertebrate biomass) were monitored in the diversion reach and a control reach at each stream for two years before, and five years after project commencement, and analyzed using age-specific models and size-density analysis to quantify the effect of flow diversion and the other environmental factors on fish biomass in the diversion reaches. Stream flow metrics that were tested included mean growing season discharge, mean winter discharge, 10th percentile growing season discharge and 10th percentile winter discharge, which represent our primary hypotheses about how the stream flow regime influences salmonid habitat quality and quantity, and thus salmonid growth and survival (Hatfield and Bruce 2000; Rosenfeld 2017; Bradford and Heinonen 2008) (detailed hypotheses are presented in the Supplementary data, Table S1 ${ }^{1}$ ). A size-density model (e.g., Bohlin et al. 1994; Rosenfeld 2014) was also applied to test how salmonid productivity across age classes was influenced by the altered flow regime in the diversion reaches of each stream.

\section{Materials and methods}

\section{Project description}

Innergex Renewable Energy Inc. (Innergex; Project infrastructure spatial files, personal communication, Sean Faulkner, March 2021) operates four RoR hydroelectric projects located in the Harrison watershed that were developed and constructed at the same time on rivers of similar size, geographical proximity, and fish community. These four projects are collectively known as the "Kwalsa Group", and include the Tipella, Lower Fire, Douglas, and Stokke projects (Fig. 1). The Douglas, Lower Fire, and Tipella projects each began operating in 2009.

The projects are located within a $12 \mathrm{~km}$ radius on four small (5-7 $\left.\mathrm{m}^{3} / \mathrm{s} \mathrm{MAD}\right)$, steep (7\%-14\% gradient), stream reaches in the Harrison River watershed, which drains into the Fraser River near Vancouver, BC. These streams are typical of those selected for RoR hydroelectric projects in BC, with short diversion reaches $(<5 \mathrm{~km}$ length) and substantial head $(\sim 300 \mathrm{~m})$ that allows for cost-effective flow diversion and power generation. All four of the study streams are third order, with steep bedrock-confined banks with no lateral secondary channels. All four streams support resident rainbow trout monocultures in the diversion reaches that are separated from anadromous reaches by large falls ( $>5 \mathrm{~m}$ high) located near the downstream end of the diversion reaches.

Each project has an instream flow requirement (IFR), a minimum flow that must be released in the diversion reach during operation, set to mitigate the effects of flow diversion and maintain fish habitat. Furthermore, a maximum diversion rate was set to ensure that flow in addition to the IFR, was available during natural high-flow periods. The IFRs and maximum diversion rates were based on a habitat-based instream flow study that followed the BC guidelines (Hatfield et al. 2007) and the BC Instream Flow Methodology (Lewis et al. 2004); a method developed for the assessment of RoR hydropower projects in BC, similar to the Physical Habitat Simulation (PHABSIM) component of the Instream Flow Incremental Methodology (Bovee 1982; Turner et al. 2016). These minimum instream flows were developed using a building block approach that included lowest flow in the winter (ranging from $0.25 \mathrm{~m}^{3} / \mathrm{s}$ to $0.50 \mathrm{~m}^{3} / \mathrm{s}$ ), with higher flows for spring spawners in June (ranging from 1.0 to $2.0 \mathrm{~m}^{3} / \mathrm{s}$ ), and during summer and fall rearing (ranging from 0.45 to $1.1 \mathrm{~m}^{3} / \mathrm{s}$ ), to create annual average IFRs of $8.7 \%$ to $21.2 \%$ MAD among streams (Table 1 ). The four projects have maximum diversion rates ranging from 7.2 to $11.1 \mathrm{~m}^{3} / \mathrm{s}$, equivalent to $144 \%$ to $170 \% \mathrm{MAD}$.

Despite application of the IFRs, the instream flow study predicted that rainbow trout habitat would decrease in the diversion reach of each stream (Douglas, $-11 \%$; Lower Fire, $-22 \%$; Stokke, $-57 \%$; Tipella, $-1 \%$ ), based on the assumption that rainbow trout parr habitat, as described by BC habitat suitability indices (Rosenfeld et al. 2016), was limited by flow during the critical low flow period in September-October. For each project, habitat was constructed and maintained to offset the predicted habitat losses as required by the federal Fisheries Act Authorization, and longterm monitoring of the response of fish to flow diversion was conducted as required by the provincial Conditional Water Licences.

\section{Environmental data collection}

Monitoring programs for the four projects employed a beforeafter control-impact (BACI) experimental design, including monitoring the project baseline for two years prior to project operation (2006-2008) and monitoring the effects of the project for five years during operation (2010-2014). Two reaches were monitored in each stream including an impact reach in the diversion reach, and a control reach located upstream of the point of diversion (Fig. 1). Field data were collected to document fish abundance, flow, water temperature, water quality, and invertebrate density in the before and after periods in both the upstream and diversion reaches. The monitoring approach and methods followed the BC guidelines (Hatfield et al. 2007) and are consistent with the DFO monitoring protocols in British Columbia and the Yukon (DFO 2012; Lewis et al. 2013).

Rainbow trout abundance and biomass were quantified using closed-site electrofishing with multiple removal passes; a standard method in BC streams that provides reliable estimates of fish density when enclosures and multiple removal passes are used (Hatfield et al. 2007; Lewis et al. 2013). Sampling was completed at five $\sim 100 \mathrm{~m}^{2}$ sites in the diversion reach and at five $\sim 100 \mathrm{~m}^{2}$ sites in the control reach at each stream during the low-flow period in the growing season: through September to mid-October of each year. Sampling sites were selected in representative good-quality fish habitats conducive to closed-site electrofishing. Two to four electrofishing passes were conducted at each site, with each pass consisting of two full circuits of the enclosure. Electrofishing effort was recorded, although effort did not differ between the

${ }^{1}$ Supplementary data are available with the article at https://doi.org/10.1139/cjfas-2020-0246. 
Fig. 1. Kwalsa Group of run-of-river hydroelectric projects, near Harrison Lake, British Columbia. Mapping conducted using ESRI Inc. (2020) with layers from Innergex (pers. comm., 2021).

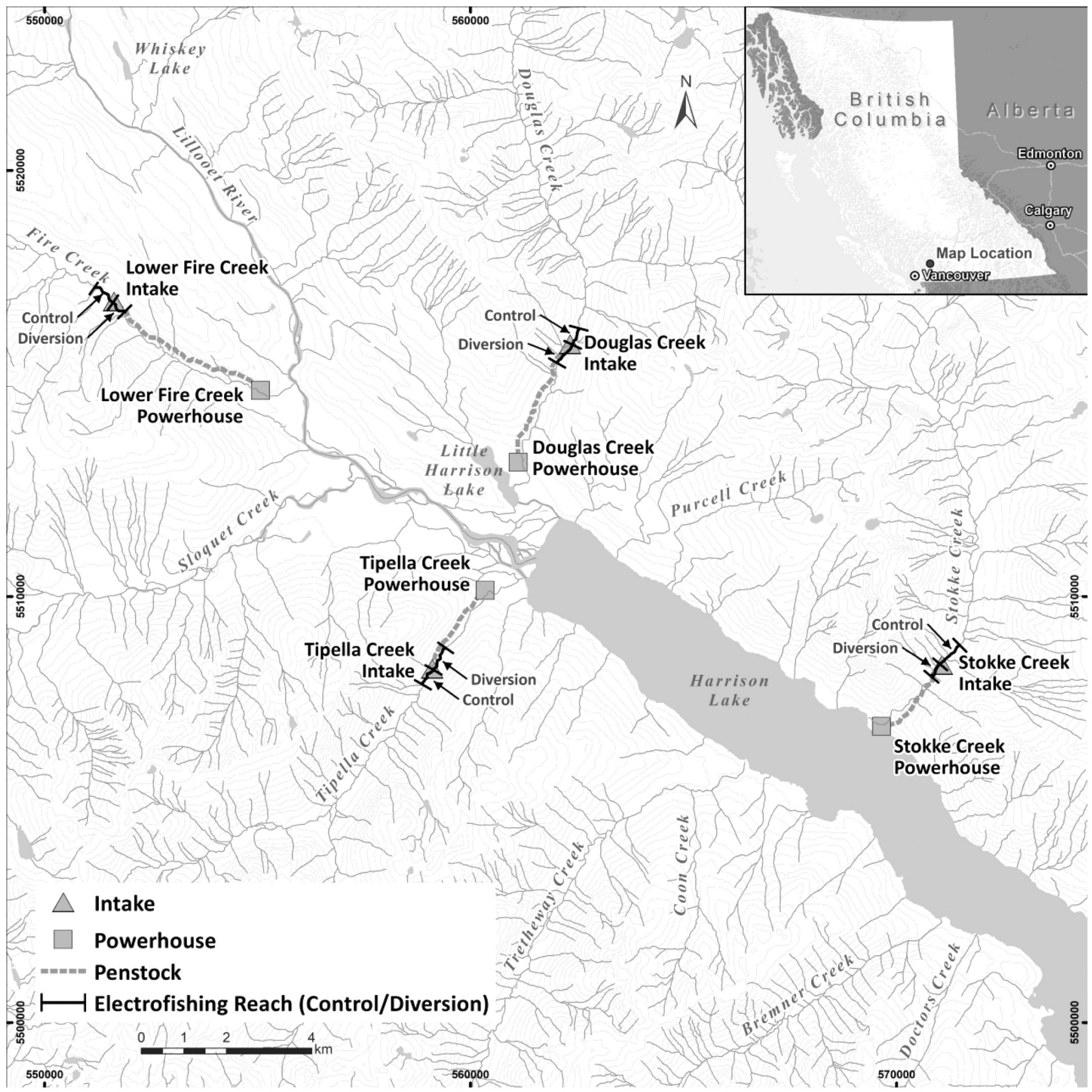

control and diversion reaches nor between the before and after periods.

All fish captured by electrofishing were processed immediately after capture. Fish were anaesthetized using ENOV, identified to species, and measured by fork length and body mass. Scale samples were collected from a subsample of rainbow trout from each life stage, at each stream, to confirm the age of each size class of fish caught. All of the anaesthetized fish were allowed to recover before being released back into the stream.

Fish density and biomass estimates were computed by age class for rainbow trout at each site using the removal depletion formulas in MicroFish V3.0, which uses the Burnham maximum likelihood estimation (Van Deventer 2006). Density and biomass by age class at individual sites were then standardized per $100 \mathrm{~m}^{2}$ to obtain estimates of rainbow trout density $\left(\mathrm{fish} / 100 \mathrm{~m}^{2}\right)$ and biomass $\left(\mathrm{g} / 100 \mathrm{~m}^{2}\right)$, which were used as the primary response variables.

The flows were monitored continuously using water level pressure sensors calibrated by flow measurements in the upstream and diversion reaches of each of the study streams, and were compiled daily for all years of the monitoring study. Flow data were missing for parts of the baseline and operational periods. Missing data during both pre- and post-project periods were infilled using a regional hydrological analysis, consisting of 
Table 1. Summary of stream characteristics including natural flow and IFRs for the Kwalsa Group of run-of-river hydroelectric project streams.

\begin{tabular}{|c|c|c|c|c|c|c|c|c|}
\hline Stream & $\begin{array}{l}\text { Diversion } \\
\text { length }(\mathrm{m})\end{array}$ & $\begin{array}{l}\text { Diversion reach } \\
\text { gradient (\%) }\end{array}$ & $\begin{array}{l}\text { Natural MAD } \\
\left(\mathrm{m}^{3} / \mathrm{s}\right)\end{array}$ & $\begin{array}{l}\text { Max. flow } \\
\text { diversion }\left(\mathrm{m}^{3} / \mathrm{s}\right)\end{array}$ & $\begin{array}{l}\text { Max. flow } \\
\text { diversion (\% MAD) }\end{array}$ & $\begin{array}{l}\text { Instream flow } \\
\text { period }\end{array}$ & $\begin{array}{l}\text { IFR } \\
\left(\mathrm{m}^{3} / \mathrm{s}\right)\end{array}$ & $\begin{array}{l}\text { IFR } \\
\text { (\% MAD) }\end{array}$ \\
\hline \multirow[t]{4}{*}{ Douglas Creek } & \multirow[t]{4}{*}{3315} & \multirow[t]{4}{*}{$10 \%$} & \multirow[t]{4}{*}{6.73} & \multirow[t]{4}{*}{11.10} & \multirow[t]{4}{*}{$165 \%$} & Jan. 1-May 30 & 0.45 & $6.7 \%$ \\
\hline & & & & & & Jun. 1-Jun. 30 & 1.80 & $26.7 \%$ \\
\hline & & & & & & Nov.1-Dec. 31 & 0.45 & $6.7 \%$ \\
\hline & & & & & & Annual & 0.71 & $10.6 \%$ \\
\hline \multirow[t]{4}{*}{ Lower Fire Creek } & \multirow[t]{4}{*}{4405} & \multirow[t]{4}{*}{$7 \%$} & \multirow[t]{4}{*}{6.39} & \multirow[t]{4}{*}{10.51} & \multirow[t]{4}{*}{$164 \%$} & Jan. 1-May 30 & 0.50 & $7.8 \%$ \\
\hline & & & & & & Sept. $16-$ Oct. 15 & 1.10 & $17.2 \%$ \\
\hline & & & & & & Oct. 16-Dec. 31 & 0.50 & $7.8 \%$ \\
\hline & & & & & & Annual & 1.36 & $21.2 \%$ \\
\hline \multirow[t]{3}{*}{ Stokke Creek } & \multirow[t]{3}{*}{2233} & \multirow[t]{3}{*}{$14 \%$} & \multirow[t]{3}{*}{4.93} & \multirow[t]{3}{*}{8.39} & \multirow[t]{3}{*}{$170 \%$} & Jan. 1-May 30 & 0.25 & $5.1 \%$ \\
\hline & & & & & & Jun. 1-Jun. 30 & 1.00 & $20.3 \%$ \\
\hline & & & & & & Jul.1-Sept. 15 & 0.45 & $9.1 \%$ \\
\hline \multirow[t]{5}{*}{ Tipella Creek } & \multirow[t]{5}{*}{2385} & \multirow[t]{5}{*}{$12 \%$} & \multirow[t]{5}{*}{4.99} & \multirow[t]{5}{*}{7.19} & \multirow[t]{5}{*}{$144 \%$} & Jan. 1-May 30 & 0.35 & $7.0 \%$ \\
\hline & & & & & & Jun. 1-Jun. 30 & 1.40 & $28.1 \%$ \\
\hline & & & & & & Jul. 1-Oct. 31 & 0.92 & $18.4 \%$ \\
\hline & & & & & & Nov.1-Dec. 31 & 0.35 & $7.0 \%$ \\
\hline & & & & & & Annual & 0.63 & $12.6 \%$ \\
\hline
\end{tabular}

Note: MAD, mean annual discharge; IFR, instream flow requirement.

multiple linear regressions with surrogate streams (LWBC 2005) [Supplementary data, Table $\mathrm{S}^{1}{ }^{1}$ (Regression equations used to fill missing stream flow data)].

Continuous water temperature data were collected using data loggers (Onset TidbiT $^{\circledR}$ ) in the upstream reach and diversion reach of each stream. Temperature data were missing for parts of the baseline and operational periods. Missing data from both pre- and post-project commencement periods were infilled using linear regression models between temperature at the target stream and temperature in the Tipella Creek diversion reach (Supplementary material, section on Temperature data ${ }^{1}$ ).

Water quality grab samples and in situ measurements were also collected at one site in each reach and during fish sampling. The parameters collected in situ during fish sampling included conductivity, alkalinity, dissolved oxygen, and turbidity. Laboratory analyses included $\mathrm{pH}$, total suspended solids, total dissolved solids, turbidity, total alkalinity, ammonia levels, nitrate levels, nitrite levels, total phosphorus, and orthophosphate. Water quality lab samples were analyzed by CARO Analytical Services of Vancouver (Supplementary material, section on Water quality data ${ }^{1}$ ).

Invertebrate data were collected at each reach and stream in a set of five drift nets ( $30 \mathrm{~cm} \times 30 \mathrm{~cm}, 250 \mu \mathrm{m}$ mesh size) placed across the stream in the downstream half of riffle habitats (SECL 2011). Sampling occurred in one year of baseline (2008) and five years during operation (2010-2014). The nets were set in the morning and left in the stream to sample for four to six hours. Invertebrate samples were processed with a minimum 300-organism sort, with identification of drift organisms down to the lowest practical taxonomic level. Biomass was determined by applying length-weight relationships or direct weighing and standardizing to the flow measured in cubic metres at the drift net locations (Supplementary material, section on Invertebrate data ${ }^{1}$ ).

\section{Data analysis: effects of diversion}

Linear mixed-effects modelling was used to test for changes in fish density and biomass within the BACI design across all sites, streams, and years of data collection. The fixed effects consist of reach (control/impact), period (before/after), and the key BACI interaction term of reach $\times$ period, which tests the hypothesis that changes in fish density and biomass will be observed only in the diversion reach after project commencement and not in the corresponding control reach. The random effects in this design include site nested within year and stream, which account for the design of the data collection and the spatial and temporal correlation between samples.

Fish density and biomass metrics were corrected for the reduction in wetted width caused by flow diversion, which could bias the comparison of before and after values. The average reduction in wetted width during flow diversion was $-9 \%$ at Douglas Creek, $-10.5 \%$ at Lower Fire Creek, $-14 \%$ at Tipella Creek, and $-31 \%$ at Stokke Creek. Fish density and biomass metrics after flow diversion that were used in the model were revised using correction factors based on the proportional change in wetted width after flow diversion commenced:

$$
\mathrm{D}_{\text {Acorr }}=\mathrm{D}_{A} \cdot \mathrm{WW}_{\text {corr }} \quad \mathrm{WW}_{\text {corr }}=1+\left(\mathrm{WW}_{a}-\overline{\mathrm{WW}_{b}}\right) / \overline{\mathrm{WW}_{b}}
$$

where $\mathrm{D}_{\text {Acorr }}$ is the corrected fish density or biomass after flow diversion, $D_{A}$ is the raw fish density or biomass after flow diversion, $\mathrm{WW}_{\text {corr }}$ is the wetted width correction factor, $\mathrm{WW}_{a}$ is the wetted width for a given sampling date in a given stream after flow diversion, and $\overline{\mathrm{WW}}_{b}$ is the average wetted width across all sampling dates in a given stream prior to flow diversion. The wetted width correction was applied for each stream and models were re-run using wetted width-corrected density and biomass. Results were similar using wetted width-corrected versus uncorrected data. Therefore, we present wetted width-corrected data only in the results, including for age-specific and size-density models.

A BACI analysis was also conducted to test for differences in flow, water temperature [maximum weekly average temperature (MWAT), and degree days $\left.>5{ }^{\circ} \mathrm{C}\left(\mathrm{DD}>5{ }^{\circ} \mathrm{C}\right)\right]$, and invertebrate density as a result of the diversion. The BACI analyses used a mixed-effects model with reach (control/impact) and period (before/after), and the reach $\times$ period BACI interaction term as fixed effects, and year and stream included as crossed random 
intercepts. Invertebrate density was measured at multiple nets in each stream; for this model, net was included as an additional random intercept nested within stream and year. Modelled BACI scores were also computed, representing the differential change after flow diversion between the impact and control reaches:

$$
\mathrm{BACI}=\left(\mu_{\mathrm{IA}}-\mu_{\mathrm{IB}}\right)-\left(\mu_{\mathrm{CA}}-\mu_{\mathrm{CA}}\right)
$$

where $\mu$ is the estimated marginal mean from the model for a given reach-period combination, where $\mathrm{I}=$ impact reach, $\mathrm{C}=$ control reach, $\mathrm{B}=$ before flow diversion, and $\mathrm{A}=$ after flow diversion .

\section{Data analysis: effects of diversion by age class}

Alterations in stream flow can have effects that differ by fish age class (Nislow and Armstrong 2012). Metrics for environmental data were developed that represent a-priori hypotheses for how flow, temperature, water quality, and drift invertebrates may predict rainbow trout density and biomass by age class (Supplementary data, Table $\left.S 1^{1}\right)$. Five age class groupings were analyzed: fry $(0+)$, parr (1+), parr $(2+)$, adult $(\geq 3+)$, and all fish.

Stream flow metrics that were hypothesized to influence salmonid growth and survival were: mean growing season discharge; mean winter discharge; 10th percentile growing season discharge; and 10th percentile winter discharge. The growing season was characterized as the period when the average weekly water temperature is $>5{ }^{\circ} \mathrm{C}$, following Coleman and Fausch (2007); typically May through October on these streams, with a winter period from November through April. Mean discharge during the growing season reflects rearing conditions throughout the growing season for rainbow trout. High flows during spring freshet can reduce habitat availability during the growing season (Nehring and Anderson 1993; Smith 2000; Laliberte et al. 2016). In contrast, the 10th percentile growing season discharge reflects the annual periods of lowest streamflow, which overlaps with the critical streamflow period in late summer and early fall that is thought to be a key habitat bottleneck for juvenile salmonid production (Harvey et al. 2006; Bradford and Heinonen 2008; Rosenfeld 2017). Mean discharge in the winter reflects rearing conditions during the overwintering period, which was hypothesized to capture the effect of flow on overwintering survival. For example, high flow conditions during winter can increase overwintering mortality, particularly of fry (Nehring and Anderson 1993; Capra et al. 2003; Gouraud et al. 2008). Low flows in winter can also result in reduced overwintering habitats due to decreased water depths, because rainbow trout prefer deep slow-moving waters for overwintering (Ford et al. 1995; Dibble et al. 2015; Heggenes et al. 2018). Therefore, the 10th percentile winter flows were included to capture the potential effects of low winter flows on overwinter survival. For data analyses, all four flow metrics representing growing season and winter conditions were standardized to the fraction of the mean annual discharge in each stream.

Water temperature data were analyzed to determine length and magnitude of the growing season, defined with two temperature metrics: MWAT and DD $>5{ }^{\circ} \mathrm{C}$. Rainbow trout prefer water temperatures of $<18{ }^{\circ} \mathrm{C}$, and temperatures of $>22{ }^{\circ} \mathrm{C}$ can be lethal, with $27^{\circ} \mathrm{C}$ considered the upper lethal temperature (Ford et al. 1995). MWAT has been commonly used to describe the summer high temperature extremes experienced by resident salmonids (Parkinson et al. 2016). Even small increases in water temperatures may decrease fish growth if food is a limiting factor due to increased energetic requirements (Railsback and Rose 1999). In contrast, mountainous streams that remain too cold during the growing season can limit summer growth and the subsequent recruitment of juvenile trout (Coleman and Fausch 2007). Therefore, DD $>5{ }^{\circ} \mathrm{C}$ was included in data analyses with the hypothesis that increased DD $>5{ }^{\circ} \mathrm{C}$ would lead to increases in juvenile growth and recruitment (Coleman and Fausch 2007).
Of the water quality parameters collected, only conductivity and alkalinity were considered for inclusion as predictors of rainbow trout biomass by age class. Conductivity and alkalinity were both hypothesized to represent a surrogate for stream productivity (Ptolemy 2005; McGrath et al. 2008). Additional water quality parameters were either not variable enough to be considered (e.g., turbidity was always clear) or had missing values during baseline periods.

Drift invertebrate data were processed into metrics of aquatic abundance $\left(\mathrm{No} . / \mathrm{m}^{3}\right)$ and total drift biomass $\left(\mathrm{mg} / 100 \mathrm{~m}^{3}\right)$. Increases in total drift biomass were hypothesized to increase rainbow trout biomass across all age classes. Drift invertebrates represent an important food source for resident salmonids, and increases in drift concentrations are predicted to increase the production potential for all age classes (Jenkins et al. 1970; Laliberte et al. 2016; Naman et al. 2017).

Initial analyses involved data exploration techniques (Zuur et al. 2010) to validate model performance and to identify and reduce collinearity among the predictor variables. Conductivity and alkalinity were found to be positively correlated $(r=0.60)$. Because conductivity was generally found to be a stronger predictor of fish density than alkalinity, conductivity was retained, and alkalinity removed from subsequent analyses. MWAT and DD > $5{ }^{\circ} \mathrm{C}$ were also found to be positively correlated $(r=0.72)$ and both MWAT and DD $>5{ }^{\circ} \mathrm{C}$ were found to be positively correlated to rainbow trout biomass. MWAT never exceeded $15{ }^{\circ} \mathrm{C}$ on any of the streams during the study period, and therefore MWAT was removed and DD $>5{ }^{\circ} \mathrm{C}$ retained in the model selection. Invertebrate drift biomass was found to be positively correlated with MAD. There was a negative relationship between fish density and invertebrate drift biomass in all of the streams except for Tipella Creek $(r=-0.36, r=-0.33, r=-0.62, r=0.06$ for Douglas Creek, Lower Fire Creek, Stokke Creek, and Tipella Creek, respectively), which suggested a top-down cropping effect of rainbow trout on invertebrates (Nyström et al. 2003; Shelton et al. 2015). Therefore, invertebrate biomass was removed as a predictor of fish biomass.

The four flow metrics hypothesized to influence salmonid production were also correlated with one another ( $r=0.45$ to 0.89 ). This was addressed by only allowing one or two flow metrics in a single model at a time. Further, the only two flow metrics that could be placed in the same model were mean growing season discharge and 10th percentile winter discharge or mean winter discharge and 10th percentile growing season discharge (the least correlated flow metrics). While these adjustments improved model performance from a statistical perspective (e.g., minimizing variance inflation), they also allow for an explicit test of which flow metric most limits fish production for specific age classes. In addition, the flow metrics were collinear with the key BACI interaction term of reach $\times$ period. Therefore, rather than forcing the typical BACI model structure, the reach $\times$ period interaction and the period terms were excluded, and streamflow was instead modeled directly.

The exploratory steps yielded a final set of fixed effects that included stream reach, conductivity, DD $>5{ }^{\circ} \mathrm{C}$, and the flow metrics of mean growing season discharge, mean winter discharge, 10th percentile growing season discharge and 10th percentile winter discharge in each of the age class models.

An all-model-combinations model-averaging procedure used the Akaike Information Criterion corrected for small sample sizes $\left(\mathrm{AIC}_{\mathrm{c}}\right)$ to determine the set of top models and most important variables to predict rainbow trout biomass. The analysis was completed using the open access program R (R Core Team 2016) and the R packages "lme4" (Bates et al. 2015) and "MuMIn" (Barton 2016). A model averaging approach is beneficial when many com-

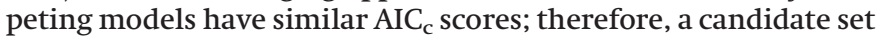
of models with $\mathrm{AIC}_{\mathrm{C}}$ scores within four points of the top model was considered $\left(\triangle \mathrm{AIC}_{\mathrm{c}}<4\right)$. The relative variable importance (RVI; also called the variable weight) of each of the variables was 
then derived, based on their summed likelihood among the candidate set of models. RVI scores occur on a scale of zero to one with higher values indicating higher importance of a variable across the top candidate models. Model averaging used the zeroaveraging method, where estimates for each parameter are calculated assuming parameters excluded from a given model have an estimate of zero (Grueber et al. 2011). Each predictor variable was also scaled by subtracting its mean and dividing by twice its standard deviation, giving all predictors a mean of zero and a standard deviation of 0.5 , and enabling them to be viewed on the same scale.

\section{Data analysis: effects of diversion on the size-density relationship}

The effect of water diversion on salmonid density was further assessed using a size-density analysis across all age classes (Allen 1969; Bohlin et al. 1994; Dunham and Vinyard 1997). If a population is space or resource limited, the number of individuals per unit area that can be supported (i.e., the productivity) is expected to be inversely related to average body size. This occurs simply because larger individuals require more resources, and this commonly results in a negative relationship between population density and average body mass. Evidence for a negative relationship between body mass and density across age classes of streamresident salmonids has been found in several studies (Bohlin et al. 1994; Dunham and Vinyard 1997; Rosenfeld 2014), and implies that some combination of space and food limitation is acting to limit population density. Shifts in the intercept and the slope of the sizedensity relationship across different streams or time periods are thus informative and can indicate factors that influence the production of fish biomass in a stream (shifts in the intercept of the sizedensity relationship), and differential fish growth or survival by age class (shifts in the slope of the size-density relationship) (Bohlin et al. 1994; Rosenfeld 2014).

The effect of water diversion on fish growth or survival by age class was tested with a size-density model using the all-model combinations mixed-effects modeling framework across all four streams described above, with log fish density as the response variable. Modelling was done on each stream individually, and on all streams combined. The predictors included log average mass (by age class), conductivity, $\mathrm{DD}>5{ }^{\circ} \mathrm{C}$, and the flow metrics of mean growing season discharge, mean winter discharge, 10th percentile growing season discharge, and 10th percentile winter discharge. The random effect structure consisted of site nested within year as random intercepts for the individual stream models, and site nested within stream and year as random intercepts in the all-streams model. Other than average mass, which tests the hypothesis that rainbow trout populations undergo selfthinning as they age in response to food or habitat limitation, the other main effects test whether the production of fish biomass in the stream (i.e., the intercept) differs with shifts in stream flow, temperature, and conductivity. Interaction terms between rainbow trout mass and conductivity, DD $>5{ }^{\circ} \mathrm{C}$, or each of the flow metrics test for differential growth or survival by age class (shifts in the slope of the size-density relationship; see Bohlin et al. 1994; Rosenfeld 2014).

To better visualize estimated shifts in the size-density relationship with changes in stream flow and water quality, we developed a series of scenarios based on the model averaged estimates of the size-density relationships predicted prior to and during water diversion. The scenarios included: (i) whether all of the other streams had increased conductivity equal to the average conductivity at Lower Fire Creek; (ii) the average decrease in growing season flows across all four streams as a result of diversion; (iii) the average decrease in winter flows across all four streams as a result of diversion; (iv) the average diversion of both growing season and winter flows; and $(v)$ the average diversion of both growing season and winter flow, plus whether the increased conductivity was equal to that observed on Lower Fire Creek.

\section{Results}

\section{Effects of diversion}

In both the before and after periods, the flow regime of all four streams was characterized by freshet flows during the growing season, a low flow period in late summer and fall, and periodic high flows early in the winter in response to high rainfall events (Fig. 2) (Supplementary data, Figure S1 ${ }^{1}$ ). Natural flows and flows diverted from the diversion reach were similar among the four project streams, with MAD ranging from 5.00 to $6.89 \mathrm{~m}^{3} / \mathrm{s}$ and average instream flow in the diversion ranging from 1.49 to $2.55 \mathrm{~m}^{3} / \mathrm{s}$, resulting in mean annual decreases in flow of $63 \%$ to $70 \%$ (Supplementary data, Table $3^{1}$ ). The flow metrics for the mean growing season discharge, 10th percentile growing season discharge, mean winter discharge, and 10th percentile winter discharge all decreased in the diversion reach (BACI, $P<0.01$ for all of the metrics).

Compliance monitoring verified that the IFRs were provided as designed, with flows meeting or exceeding IFRs when projects were operating $>99 \%$ of the operating period days (Tipella, $99.8 \%$; Lower Fire Creek, 99.5\%; Douglas, 99.8\%; and Stokke, 99.6\%). The consistent, seasonally adjusted IFRs and maximum flow diversion rates resulted in frequent spills (periods when inflows at the diversion intake exceeded maximum diversion rate), exhibiting all seasonal components of the natural flow regime. Even in the lowest flow month, the observed instream flow was $\geq 18 \%$ of the natural monthly discharge.

Flow diversion was associated with an increase in rainbow trout population density (11\% to $115 \%$ higher, $\mathrm{BACI}$ score $=3.87, P=0.06$ ) and biomass ( $35 \%$ to $157 \%$ higher, BACI score $=77.1, P=0.003)$ in the diversion reach in all four streams after operations compared to before operations (Supplementary data, Table S7 ${ }^{1}$ ) (Fig. 3). Rainbow trout biomass increased in the diversion reach from 74.8 to $158.7 \mathrm{~g} / 100 \mathrm{~m}^{2}$ prior to water diversion, to 116.0 to $237.5 \mathrm{~g} / 100 \mathrm{~m}^{2}$ during water diversion across all streams (Douglas $=55.1 \mathrm{~g} / 100 \mathrm{~m}^{2}$, $54 \%$; Lower Fire Creek = $111.9 \mathrm{~g} / 100 \mathrm{~m}^{2}, 74 \%$; Stokke $=117.5 \mathrm{~g} / 100 \mathrm{~m}^{2}$, $157 \%$; Tipella $=55.5 \mathrm{~g} / 100 \mathrm{~m}^{2}, 35 \%$ ). Biomass increased across all age classes in each stream, except for age $0+$ rainbow trout in Tipella Creek, which decreased in biomass by $18 \%$. All of the results presented here are adjusted by the reduction in wetted width of the stream.

Peak summer water temperatures (MWAT) and growing season length (DD $>5{ }^{\circ} \mathrm{C}$ ) did not change significantly with water diversion $\left(\right.$ MWAT BACI $=0.18, \mathrm{P}=0.58$; $\mathrm{DD}>5{ }^{\circ} \mathrm{C} \mathrm{BACI}=33.9, \mathrm{P}=0.24$ ). Water temperatures in the diversion reach were similar in the four project streams, with before and after MWAT ranging from 10.7 to $13.8^{\circ} \mathrm{C}$ and 10.7 to $12.3^{\circ} \mathrm{C}$ among streams, respectively, and mean annual changes of $-0.2 \%$ to $3.2 \%$ among streams (Supplementary data, Table S4${ }^{1}$ ). Mean annual changes in DD $>5{ }^{\circ} \mathrm{C}$ ranged from $3.7 \%$ to $6.6 \%$ among the streams, and were greatest in April and August and least in June and July. Water quality parameters did not differ substantially between the upstream and diversion reaches in the after period, indicating minimal project effects on water quality as a result of diversion (Supplementary data, Table $5^{1}$ ).

Prior to operation, invertebrate drift biomass was similar among the four project streams (Supplementary data, Table $S 6^{1}$ ), with mean biomass in the diversion reaches ranging from $0.15 \mathrm{~g} / \mathrm{m}^{3}$ to $0.28 \mathrm{~g} / \mathrm{m}^{3}$ and in the control reaches ranging from $0.19 \mathrm{~g} / \mathrm{m}^{3}$ to $0.27 \mathrm{~g} / \mathrm{m}^{3}$. Invertebrate drift biomass was lower in both control and diversion reaches in the after period, and marginally more so in the diversion reaches; however, these differences were not significant in the BACI test (BACI score $=-0.027, P=0.48$ ). 
Fig. 2. Average flow regime (2005-2014) by reach for (a) Douglas Creek, $(b)$ Lower Fire Creek, $(c)$ Stokke Creek, and $(d)$ Tipella Creek before and after water diversion commenced on each run-of-river hydroelectric project. During the pre-project baseline period the flows in the control reach were the same as flows in the diversion reach.

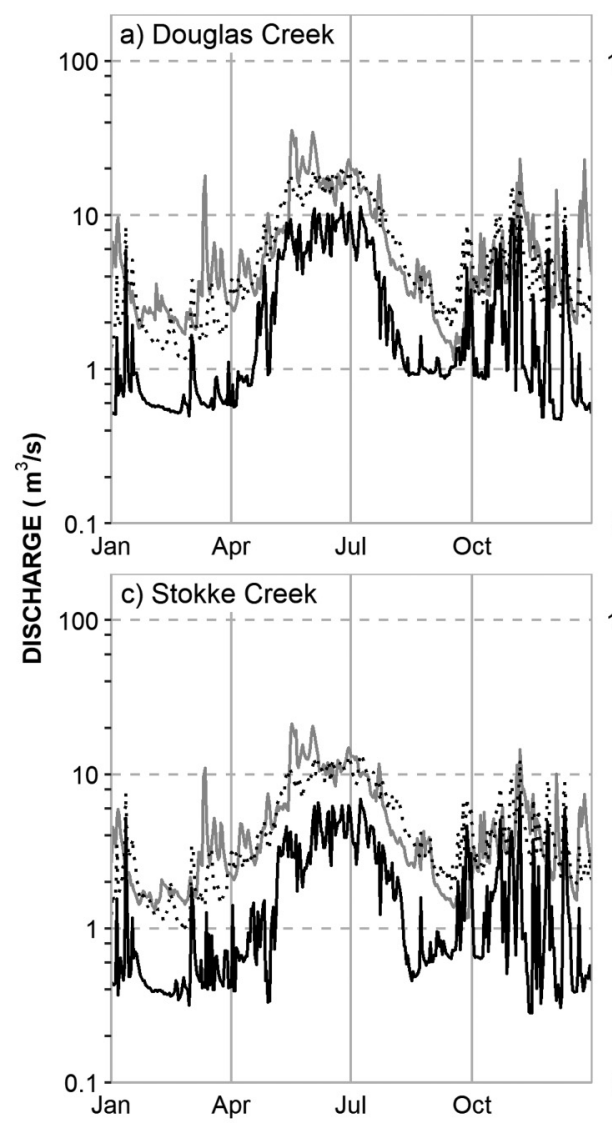

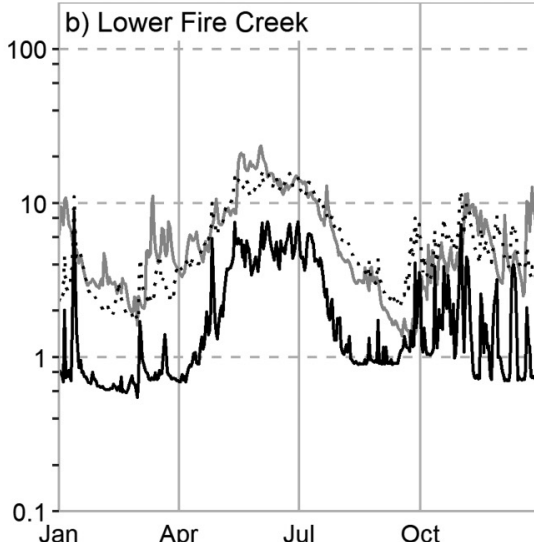

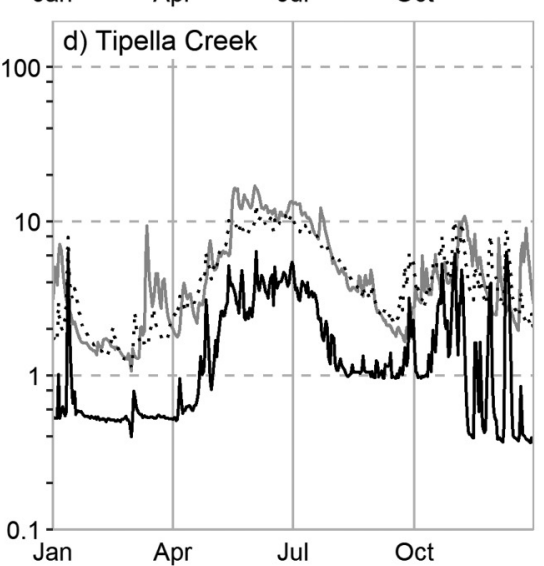

\section{Reach \\ - Both Reaches-Before \\ ... Control-After}

- Diversion-After

Fig. 3. Average rainbow trout $(a)$ density $\left(\right.$ No. $\left./ 100 \mathrm{~m}^{2}\right)$ and $(b)$ biomass $\left(\mathrm{g} / 100 \mathrm{~m}^{2}\right)( \pm \mathrm{SE})$ before and after commencement of water diversion at four run-of-river hydroelectric projects in British Columbia. Monitoring occurred at two reaches at each stream: in a diversion reach where flow was reduced, and an upstream control reach where the natural flow regime was maintained.
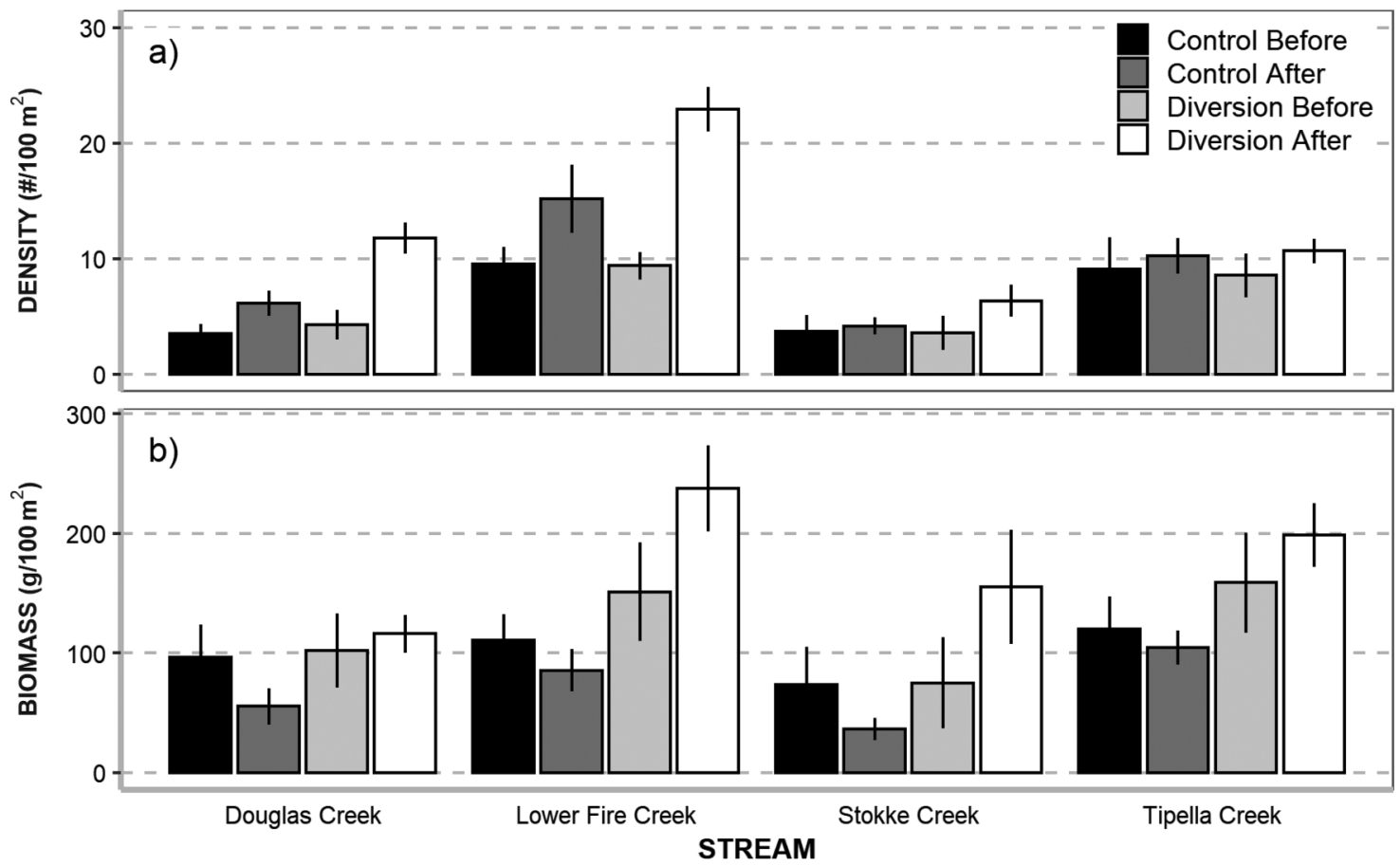

- Published by Canadian Science Publishing 
Fig. 4. Model averaged parameter estimates for the most important variables based on relative variable importance (RVI) that explain rainbow trout biomass for: (a) All Fish; (b) Fry (0+); (c) Parr (1+); (d) parr (2+); (e) adult (3+) in four streams influenced by run-of-river water diversion in British Columbia.

\section{a) All Fish Biomass}

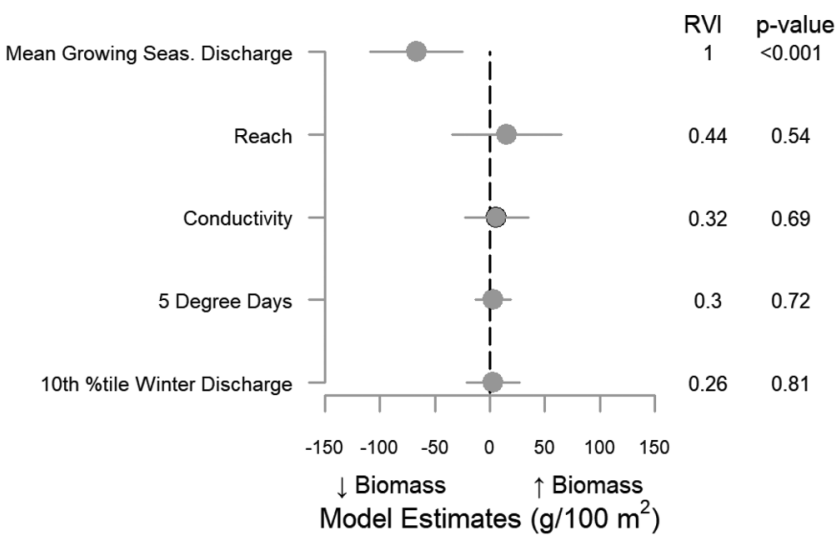

c) Parr (1+) Biomass

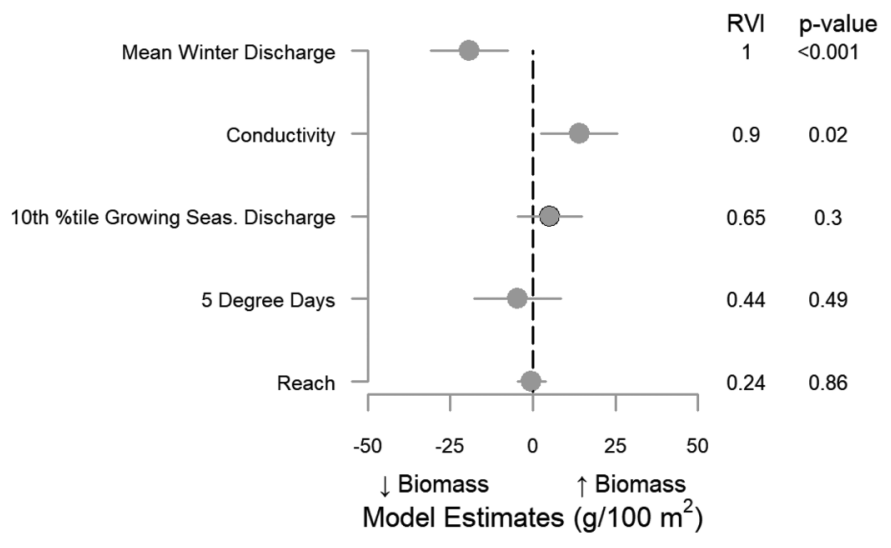

e) Adult (3+) Biomass

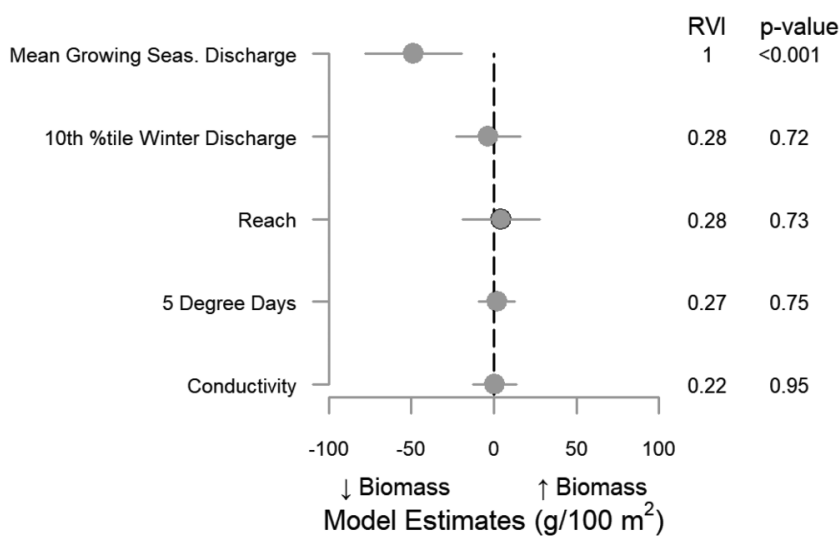

Effects of diversion by age class

Rainbow trout age classes differed in their response to stream flow, water temperature, and conductivity, with flow during the growing season as the most important variable, explaining the biomass of older age classes; water temperature and conductivity were more important for the younger age classes (Fig. 4; Supplementary data, Table $\mathrm{S} 8^{1}$ ). Discharge was the most important physical variable, explaining the change in total rainbow

\section{b) Fry (0+) Biomass}

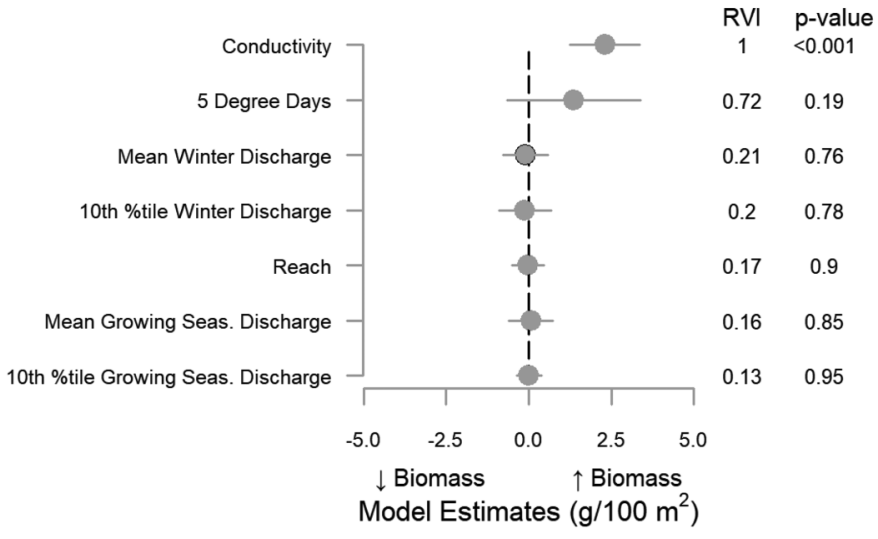

d) Parr (2+) Biomass

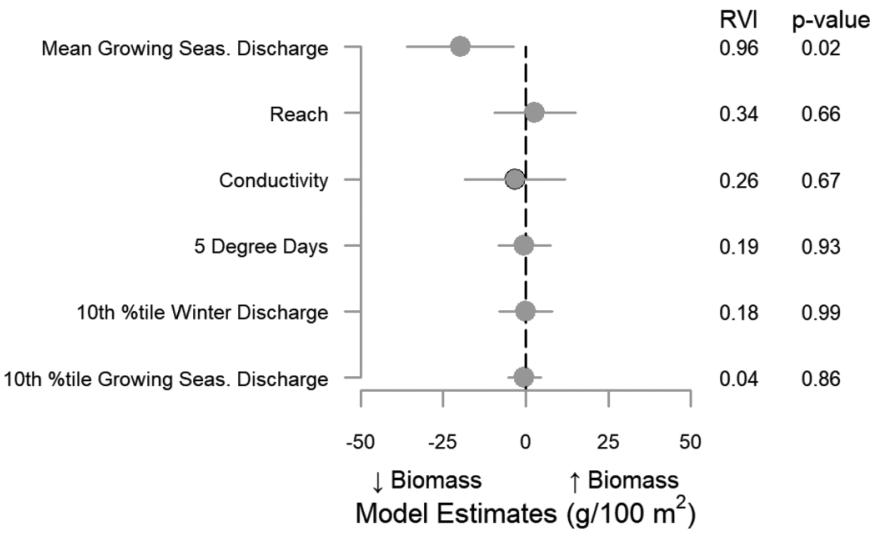

trout biomass, with higher biomass of all age classes combined at lower mean growing season discharge (Fig. 4a: RVI $=1$, $P<0.001$ ); no other variables significantly explained total rainbow trout biomass.

The biomass of rainbow trout fry was higher with increased conductivity in the stream and DD $>5{ }^{\circ} \mathrm{C}$ (Fig. $4 b$ : $\mathrm{RVI}=1$, $P<0.001$ and RVI $=0.72, P=0.01$, respectively). In contrast, none of the four-flow metrics strongly explained fry biomass. 
Fig. 5. Rainbow trout size-density relationships (log-log scale) in four streams influenced by run-of-river water diversion in British Columbia. Rainbow trout age classes are shown as well as reaches and periods of monitoring. Each point represents average density for each age class each year of sampling across five sites per reach at each stream. Lines represent model-averaged estimates from top models of rainbow trout density (see Fig. 6).
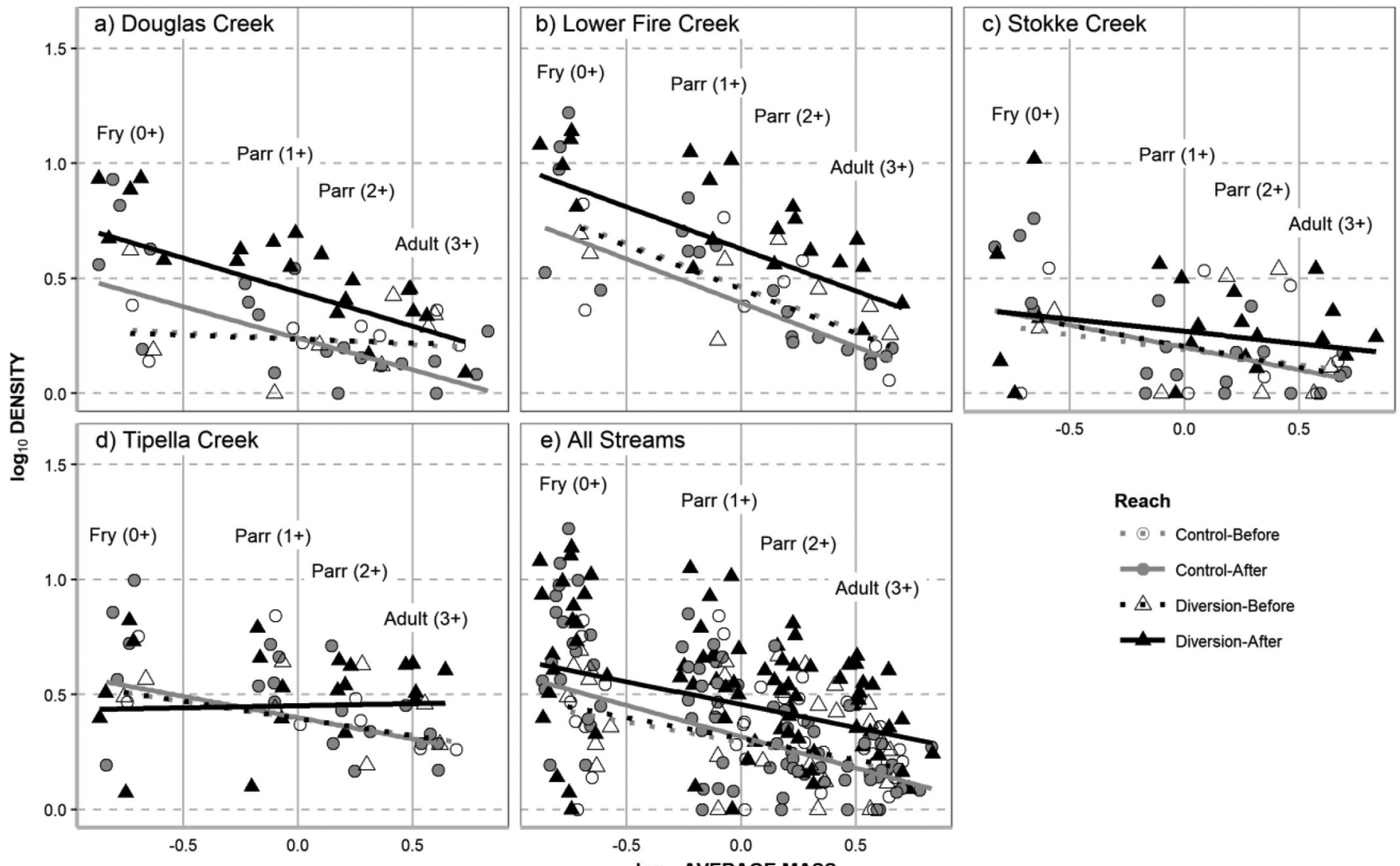

The biomass of rainbow trout parr (1+) was greater with reduced mean winter discharge in the previous winter and with higher conductivity in the stream (Fig. $4 c$ : RVI $=1, P<0.001$ and RVI $=0.9, P<0.001$, respectively). As mean winter discharge increased, the biomass of parr $1+$ measured at the end of the subsequent growing season decreased. The biomass of parr 1+ was also greater with increased 10th percentile growing season discharge, which is consistent with the original hypothesis that low flows in late summer limit the production of parr, although the relationship was weaker than for mean winter discharge (Fig. $4 c$ : $\mathrm{RVI}=0.65, P=0.05$ ). Mean growing season discharge, 10 th percentile winter discharge, and temperature during the growing season (DD $>5^{\circ} \mathrm{C}$ ) were not important predictors of parr $1+$ biomass.

For the older age classes (parr 2+, and adult $3+$ ), biomass was greater with lower mean growing season discharge (Figs. $4 d$ and $4 e:$ all RVI $\geq 0.96, P<0.001$ ), whereas all of the other variables were weak predictors. As mean growing season flow increased, the biomass of the older age classes measured at the end of the growing season decreased.

\section{Effects of diversion on the size-density relationship}

The production of rainbow trout in each stream across age classes increased after flow diversion in the diversion reach but not the control reach. This effect can be viewed via an increase in the intercept of the size-density relationship in the diversion reach after operations commenced in all four streams (Fig. 5; Supplementary data, Table $\mathbf{S 9}^{1}$ ). Across all of the streams and reaches, rainbow trout population density decreased as body mass increased with age, resulting in a negative relationship between population density and body mass (Figs. $5 e$ and 6 : RVI = $1, P<0.001$, average slope coefficient $=-0.23$ ). Each stream had a different size-density relationship; for example, Stokke Creek and Tipella Creek have a shallower size-density slope than, in particular, Lower Fire Creek, owing to the lower production of fry (Fig. 5). Average slopes across all of the streams and reaches ranged from +0.02 to -0.38 , and there was no consistent shift in the slope of the size-density relationship after diversion (Supplementary data, Table $S 9^{1}$ ).

The environmental variables of stream flow and conductivity, but not temperature, influenced rainbow trout production across age classes, including shifts in the intercept and slope of the size-density relationship (Figs. 6 and 7; Supplementary data, Table $S 10^{1}$ ). Higher stream conductivity increased rainbow trout density across all age classes (Fig. 6 : $R V I=1, P=0.06$ ), and resulted in a steeper slope of the size-density relationship (conductivity $\times$ rainbow trout mass interaction: $R V I=1, P<0.001$ ). Lower mean winter discharge as a result of diversion increased rainbow trout population density across all age classes (i.e., a higher intercept) (Fig. 6 : RVI $=1, P=0.01$ ) and steepened the slope of the sizedensity relationship (mean winter discharge $x$ rainbow trout mass interaction: $\mathrm{RVI}=1, P<0.001$ ). Lower mean growing season discharge as a result of diversion did not affect rainbow trout density across all age classes (Fig. 6 : $R V I=1, P=0.53$ ), but did result in a shallower slope of the size-density relationship (mean growing season discharge $\times$ rainbow trout mass interaction: $\mathrm{RVI}=1, P<0.001)$. The 10th percentile growing season discharge, 10th percentile winter discharge, and DD $>5{ }^{\circ} \mathrm{C}$ did not have a 
Fig. 6. Model-averaged estimates for the most important variables that explain rainbow trout density within the size-density relationship from four streams influenced by run-of-river water diversion in British Columbia (see Figs. 5 and 7 for model-averaged predictions). All of the main effects (except rainbow trout mass) act on the intercept of the size-density relationship, whereas all interactions with rainbow trout mass act on the slope of the size-density relationship. Interaction terms with rainbow trout mass can be interpreted as follows: positive model estimates indicate a shallower slope of the size-density relationship (e.g., as mean winter discharge increases the slope becomes more positive), and negative model estimates indicate a steeper slope of the size density relationship (e.g., as conductivity and growing season discharge increases the slope becomes more negative).

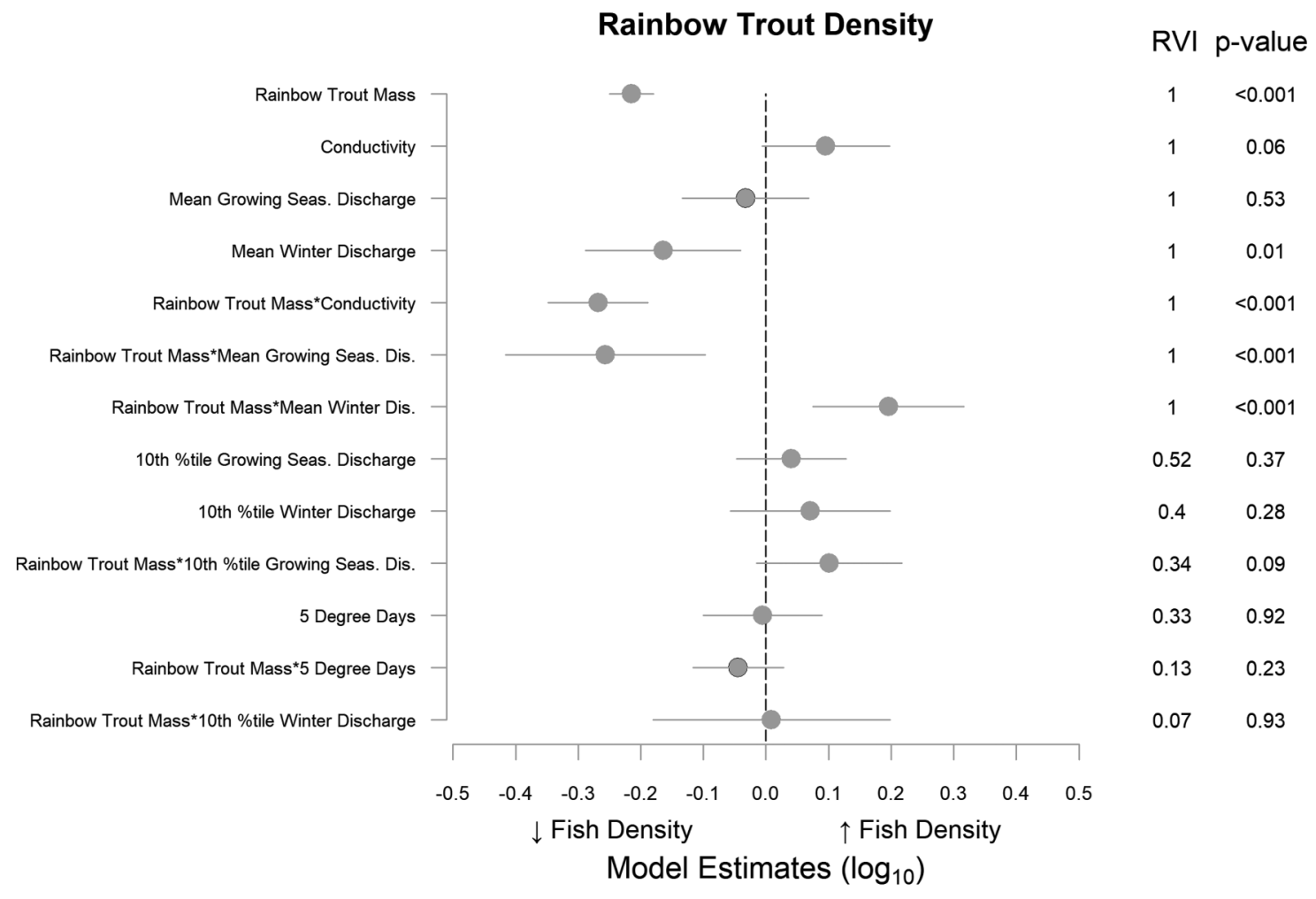

strong effect on the intercept and slope of the rainbow trout size-density relationship.

Based on the model averaged estimates shown in Fig. 6, we developed scenarios to better visualize predicted shifts in the size-density relationship with changes in stream flow and conductivity compared with conditions prior to diversion (Fig. 7). If all of the streams were to have similar conductivity to Lower Fire Creek, we estimated that fry production would be higher than if the conductivity was the average of all streams (Fig. 7a). Water diversion during the winter increased rainbow trout biomass, primarily for juveniles (Fig. $7 b$ ), whereas water diversion during the growing season increased adult production but decreased juvenile production (Fig. 7c). Taken together, average water diversion throughout the year predicts the increases in rainbow trout biomass across all age classes (Figs. $5 e$ and $7 d$ ). Finally, increasing stream conductivity in addition to water diversion throughout the year results in an increase in production across all age classes, particularly for the younger age classes (Fig. 7e).

\section{Discussion}

\section{Effects of diversion}

We observed a positive fish response to water diversion at RoR projects in this study, with increases in rainbow trout biomass in all four streams. This is a surprising result given that $92 \%$ of papers in the literature on altered flow regimes report negative ecological responses, and only $13 \%$ of papers report positive responses (Poff and Zimmerman 2010). A few of the literature examples of harmful effects of water diversion are: decline in individual fish biomass at Czech RoR projects (Kubečka et al.
1997); decrease in adult trout population densities in French diversion reaches (Sabaton et al. 2008); decreases of $42 \%-53 \%$ in brown trout (Salmo trutta) biomass in Belgium diversion reaches (Ovidio et al. 2008); and decreased fish species richness among 23 RoR projects in the UK (Bilotta et al. 2016). Further, positive responses to altered flow regimes have typically been associated with increased riparian or aquatic invertebrate production rather than increased fish production (Poff and Zimmerman 2010).

The current literature also indicates that fish abundance may decline in response to elevated flows (Poff and Zimmerman 2010). Nehring and Anderson (1993) found that the abundance of rainbow and brown trout declined due to reduced fry habitat related to increased velocities during high springtime flows (490\% MAD) in the South Platte River, Colorado, USA. Cattanéo et al. (2002) found that the population density of brown trout fry decreased with increasing flow during emergence across 30 French stream reaches. Tissot et al. (2017) found that high flows during spring and spawning were drivers of brown trout abundance in the diversion reaches of four French streams, accounting for $20 \%-$ $75 \%$ mortality, whereas extreme high flows accounted for up to $90 \%$ mortality.

In light of the relevant literature, our results may differ from those elsewhere because the proportion of flow withdrawn from the diversion reach in the study streams, although substantial, was lower than for hydroelectric projects reported on in the literature, and because the steep diversion reaches maintained high habitat suitability, even at low flows. Declines in fish biomass reported in the literature typically occur from streams where a 
Fig. 7. Estimated effects for the rainbow trout size-density relationship (log-log scale) averaged across four streams influenced by run-ofriver water diversion in British Columbia during pre-project baseline conditions (dashed line) compared with the following scenarios (solid lines): (a) whether all of the other streams had increased conductivity equal to the average conductivity at Lower Fire Creek; (b) the average decrease in growing season flows as a result of diversion; $(c)$ the average decrease in water flows in winter as a result of diversion; (d) diversion of both growing season and winter water flows; and $(e)$ the average water diversion plus increased conductivity. A shallower slope can occur with: increased mortality of fry and parr 1+, and (or) increased growth or survival of parr 2+ and adult 3+. A steeper slope can occur with: increased growth or survival of fry and parr 1+, and (or) decreased growth or survival of parr 2+ and adult 3+. The scenarios are derived from model-averaged estimates ( $\pm 95 \%$ confidence interval) of rainbow trout density shown in Fig. 6.
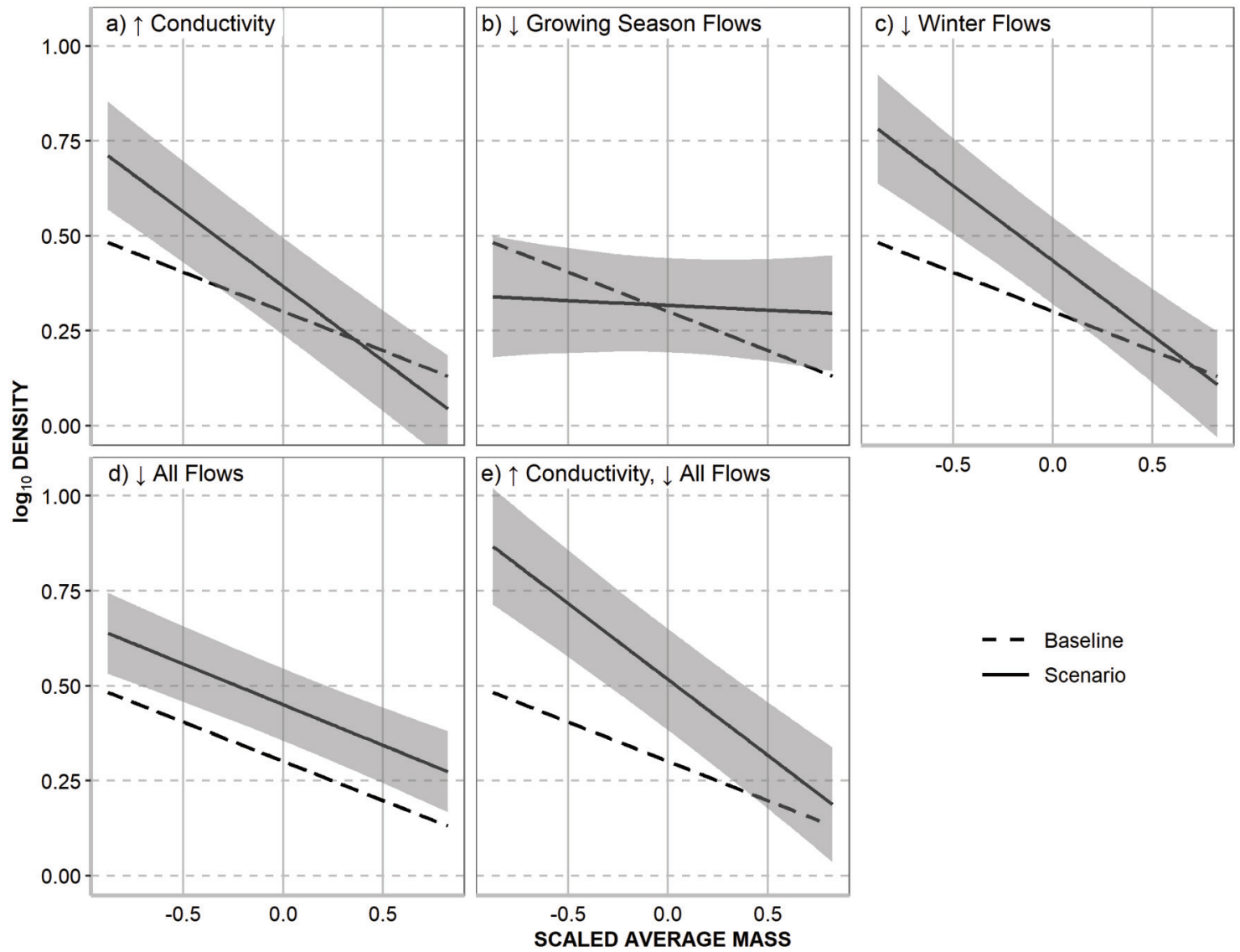

higher proportion of water was diverted compared with these projects. For example, the amount of flow removed can vary widely depending on the time of year and across jurisdictions, with up to $100 \%$ of flow being diverted in some streams (Nakamura 2013), compared with the $63 \%-70 \%$ observed in this study. Only large reductions in stream flow have been observed to consistently affect fish populations. For example, Baran et al. (1995) found the change in juvenile and total biomass was positively correlated with the \%MAD in a study of 16 hydroelectric projects on Pyrenean streams. They also found that biomass increased when flows were $>5 \% \mathrm{MAD}$, but decreased at flows of $<5 \%$ MAD. In five of six rivers in New Zealand where IFRs between 3\% to 12\% MAD were maintained in the diversion reaches, trout populations and invertebrates increased in some streams (Jowett and Biggs 2006). The consistent seasonal IFRs and maximum flow diversion rate ( $\sim 150 \%$ MAD) of the Kwalsa Group projects maintained instream flows in excess of $18 \%$ MAD in the lowest flow month (April), and allowed frequent higher flow releases at various magnitudes, creating the temporal variability in streamflow that is considered essential to sustain native diversity under the natural flow regime paradigm (Poff et al.1997).

Our results may also reflect conditions specific to the small, high gradient streams of this study, which are typical of RoR projects in BC. High gradient and confined channels show relatively less change in depth and wetted width than do lower gradient streams, thereby maintaining more suitable habitat at lower flows than those typically studied in the literature. Generalized 2D modelling of habitat quality and quantity for rainbow trout predicts relatively lower quantities of juvenile habitat, compared with adult habitat, in high gradient streams at a given stream size (Laliberte et al. 2014). Further, longitudinal and aerial production potential was found to reach a maximum at low-tomedium stream size in high gradient streams (Laliberte et al. 2016).

Our findings of minimal effect of these projects on water quality are consistent with other studies of RoR projects (Jesus et al. 2004; Wu et al. 2009), and are consistent with review papers that do not identify water quality as a key concern (Anderson et al. 2015). Invertebrate drift biomass decreased marginally on the Kwalsa Group streams in the after period (11\% decrease compared with the control), which is consistent with a study of four catchments in the central Italian Alps, where ecological quality was considered good in diversion reaches and 5\%-10\% MAD was maintained (Quadroni et al. 2017). Flow diversion can cause significant reductions in macroinvertebrates, particularly where a larger percentage of the flow is diverted (e.g., $90 \%$ summer discharge in Wills et al. 2006), but the relatively lower rates of flow diversion in the project streams (63\%-70\%) compared with typical Hydro projects may have limited harmful effects. Invertebrate biomass was negatively correlated with the biomass of age $1+$ trout in this 
present study, suggesting a top-down effect, as has been observed in other trout streams (Nyström et al. 2003; Shelton et al. 2015).

\section{Effects of diversion by age class}

Rainbow trout biomass by age class differed in response to water diversion and in response to changes in flow, water temperature, and conductivity. This result is generally consistent with previous empirical observations and bioenergetic modelling predictions of life-stage specific responses to variable environmental conditions such as flow, temperature, and habitat (Baltz et al.1991; Korman et al. 2011; Laliberte et al. 2016). Changes in food availability, flow, and temperature all have energetic consequences for fish that will vary as fish age, due to size-based differences in diet, swimming ability, and habitat use (Lobón-Cerviá 2008; Rosenfeld 2014).

The biomass of rainbow trout fry increased with stream productivity and length of growing season, but was unaffected by water flow. Fry emerge in July and early August in the study streams, when freshet has subsided to flows at the growing season minima, and water temperatures are near the seasonal maxima; such conditions are expected to promote fry growth and survival. MWAT averaged from 10.5 to $13.9^{\circ} \mathrm{C}$, below the upper temperature preference of $<18^{\circ} \mathrm{C}$ (Ford et al. 1995; Railsback and Rose 1999). Average DD $>5{ }^{\circ} \mathrm{C}$ for these streams ranged from 1250 to 1624 on average among the streams, but did decrease to $<1000$ DD in three streams in one year, reaching levels that may impair fry growth and (or) survival (Coleman and Fausch 2007).

Parr 1+ biomass decreased with increasing flows during the previous winter (November-March). Rain driven flood events are common in November following annual sampling; accordingly, the impact of winter flow on parr 1+ biomass detected here likely reflects the effect of floods in the fall when they were fry. The literature reports decreased trout abundance following flooding in the post-emergence period for fry (Nehring and Anderson 1993; Cattanéo et al. 2002; Gouraud et al. 2008) and greater susceptibility to displacement by high flows for younger, smaller salmonids (Irvine 1986; Heggenes 1988). Reductions in high flows, such as occurred here with flow regulation, have been found to increase the survival of emerging rainbow trout and brown trout fry (Capra et al. 2003; Gouraud et al. 2008). Parr 1+ biomass was marginally reduced by 10th percentile growing season discharge, consistent with the original hypothesis that late summer low flows limit the production of parr.

For the older age classes of rainbow trout (parr 2+, adult 3+), the only variable observed to affect rainbow trout biomass was a reduction in flows during the growing season. All of the other variables were weak predictors of the biomass of rainbow trout parr 2+ and adults. This may reflect increased habitat availability for older age classes of rainbow trout during the growing season in the diversion reach of these streams, and reduced metabolic costs of foraging and maintaining position for fish, thus increasing the amount of energy available for growth (Cleary et al. 2012). Laliberte et al. (2014) predicts declines in usable habitat availability for adult rainbow trout in steep gradient streams with greater flows. Further, more recent analyses that integrate physical habitat models with bioenergetic approaches also predict declines in production potential for adult rainbow trout in steep gradient streams with higher flows (Laliberte et al. 2016). The opposite may be true for low gradient streams, highlighting the importance of environmental context to understanding fish flow relationships.

\section{Effects of diversion on the size-density relationship}

We successfully applied a size-density approach to test how rainbow trout productivity across age classes were affected by water diversion. Decreases in abundance with increasing mass within a species is commonly referred to as self-thinning and indicates that some combination of food or space is acting to limit population density. Both the intercept and slope of this relationship are informative and can indicate factors that influence the production of fish biomass in a stream and differential fish growth or survival by age class (Bohlin et al. 1994; Dunham and Vinyard 1997; Rosenfeld 2014). The observed increase in the intercept of the size-density relationship in the diversion reach of each stream, but not the control reach, provides a novel illustration of the increase in rainbow trout biomass as a result of flow diversion.

Across all streams and reaches, rainbow trout population density decreased as body mass increased with age, resulting in a negative relationship between population density and body mass, with an average slope coefficient of -0.21 ( \pm 0.018$)$. However, each stream had a different size-density relationship; for example, Stokke Creek and Tipella Creek had a shallower sizedensity relationship than, in particular, Lower Fire Creek, owing to the lower production of fry. Typical slopes of the body mass abundance regression in stream resident salmonids under the assumptions of energetic equivalence are generally closer to -0.90 (Bohlin et al. 1994). Significant deviations in self-thinning relationships have been observed in salmonids, including much shallower slopes for some populations (Dunham and Vinyard 1997) and phased size-density relationships with shallow slopes in early life and steeper slopes as resident trout approach adulthood (Lobón-Cerviá 2008; Rosenfeld 2014). The relatively shallow slopes observed in this study indicate that self-thinning is occurring, but that these populations are likely below the carrying capacity of the stream sites for younger age classes. Our results also support observations by Lobón-Cerviá (2008) and Rosenfeld (2014) of unequal energy availability across cohorts as a result of size- and age-based differences in swimming ability, diet, and habitat use, and subsequent shifts in growth and mortality. In our study, we observed that juveniles were limited by high winter flows and stream productivity, whereas older fish were limited by high freshet flows during the growing season.

\section{Summary}

In summary, our key finding of an increase in rainbow trout biomass in response to flow diversion was surprising in the context of the literature documenting the harmful effects of flow withdrawal on salmonids. The positive salmonid response to flow diversion was aided by consistent release of the instream flow requirement, and also by a restricted maximum diversion rate, which allowed frequent spills throughout the year, increasing the instream flow release and maintaining the features of the natural flow regime. These results apply to these four RoR hydro projects located in coastal $\mathrm{BC}$, and the rainbow trout populations studied, and could be reasonably extrapolated to streams in southwestern BC with similar hydrology, gradient, and RoR project design, given the observed importance of hydrology in explaining trout abundance elsewhere (e.g., across diversion reaches in France, Tissot et al. 2017). However, the effects of water diversion on fish populations will ultimately depend on flow regime, stream size, gradient, productivity, and temperature, with fish species, age, and body size also influencing the response (Bilotta et al. 2016; Laliberte et al. 2016; Gibeau et al. 2017). The results may be broadly applicable; however, extrapolation of our results to other streams should be done cautiously, as responses to flow diversion are expected to vary. Further work could also test additional hydrologic metrics that were not tested in this study, such as the indicators of hydrologic alteration (Gao et al. 2009). Overall, investments in monitoring the potential effects of hydroelectric development on freshwater biodiversity are essential, and in the case of RoR can result in win-win scenarios, with confident management of flows that balances energy production and maintenance of aquatic ecosystem services, and allows 
explicit consideration of trade-offs between development and conservation.

\section{Acknowledgements}

Matt Kennedy of Innergex Renewable Energy provided the funding, direction, and management support for this study. Scott Babakaiff of MFLNRORD, and Vince Busto and Herb Klassen of DFO provided important comments on the study design and execution. Kirsten Lyle and Isabelle Deguise provided support during study execution. Consultant teams from Environmental Dynamics Inc., and Summit Environmental provided additional field data. Many thanks to the Ecofish field and office team that collected the data throughout the seven years of monitoring.

\section{References}

Abbasi, T., and Abbasi, S.A. 2011. Small hydro and the environmental implications of its extensive utilization. Renew. Sustain. Energy Rev. 15(4): 2134-2143. doi:10.1016/j.rser.2010.11.050.

Allen, K.R. 1969. Limitations on production in salmonid populations in streams. In Symposium on Salmon and Trout in Streams. Edited by T.G. Northcote. Institute of Fisheries, University of British Columbia, Vancouver, BC. pp. 3-13.

Anderson, D., Moggridge, H., Warren, P., and Shucksmith, J. 2015. The impacts of "run-of-river" hydropower on the physical and ecological condition of rivers. Water Environ. J. 29(2): 268-276. doi:10.1111/wej.12101.

Ansar, A., Flyvbjerg, B., Budzier, A., and Lunn, D. 2014. Should we build more large dams? The actual costs of hydropower megaproject development. Energy Policy, 69: 43-56. doi:10.1016/j.enpol.2013.10.069.

Baltz, D.M., Vondracek, B., Brown, L.R., and Moyle, P.B. 1991. Seasonal changes in microhabitat selection by rainbow trout in a small stream. Trans. Am. Fish. Soc. 120(2): 166-176. doi:10.1577/1548-8659(1991)120<0166:SCIMSB > 2.3.CO;2.

Baran, P., Delacoste, M., Dauba, F., Lascaux, J.M., Belaud, A., and Lek, S. 1995. Effects of reduced flow on Brown Trout (Salmo Trutta L.) populations downstream dams in French Pyrenees. Regul. Rivers: Res. Mgmt. 10(2-4): 347-361. doi:10.1002/rrr.3450100226.

Barton, C. 2016. MuMIn: Multi-Model Inference. R package version 1.15.6.

Bates, B., Maechler, M., Bolker, B., and Walker, S. 2015. Fitting linear mixedeffects models using lme4. J. Stat. Softw. 67(1): 1-48. doi:10.18637/jss.v067. i01.

Baxter, R.M. 1977. Environmental effects of dams and impoundments. Ann. Rev. Ecol. Syst. 8: 255-283.

Bilotta, G.S., Burnside, N.G., Gray, J.C., and Orr, H.G. 2016. The effects of run-of-river hydroelectric power schemes on fish community composition in temperate streams and rivers. PLos One, 11(2): e0154271. doi:10.1371/journal. pone.0154271. PMID:27191717.

Bohlin, T., Dellefors, C., Faremo, U., and Johlander, A. 1994. The energetic equivalence hypothesis and the relation between population density and body size in stream-living salmonids. Am. Nat. 143(3): 478-493. doi:10.1086/ 285614.

Bovee, K.D. 1982. A guide to stream habitat analysis using the instream flow incremental methodology. Instream Flow Information Paper No. 12. FWS OBS-82/26. Western Energy and Land Use Team, Office of Biological Services, Fish and Wildlife Service, US Department of the Interior, Washington, DC.

Bradford, M.J., and Heinonen, J.S. 2008. Low flows, instream flow needs and fish ecology in small streams. Can. Water Resour. J. 33(2): 165-180. doi:10.4296/ cwrj3302165.

Cattanéo, F., Lamouroux, N., Breil, P., and Capra, H. 2002. The influence of hydrological and biotic processes on brown trout (Salmo trutta) population dynamics. Can. J. Fish. Aquat. Sci. 59(1): 12-22. doi:10.1139/f01-186.

Capra, H., Sabaton, C., Gouraud, V., Souchon, Y., and Lim, P. 2003. A population dynamics model and habitat simulation as a tool to predict brown trout demography in natural and bypassed stream reaches. River Res. Appl. 19(5-6): 551-568. doi:10.1002/rra.729.

Cleary, J.S., Bradford, M.J., and Janz, D.M. 2012. Seasonal and spatial variation in lipid and triacylglycerol levels in juvenile chinook salmon (Oncorhynchus tshawytscha) from the Bridge River, British Columbia. Limnologica, 42(2): 144150. doi:10.1016/j.limno.2011.10.003.

Coleman, M.A., and Fausch, K.D. 2007. Cold summer temperature limits recruitment of age-0 cutthroat trout in high-elevation Colorado streams. Trans. Am. Fish. Soc. 136(5): 1231-1244. doi:10.1577/T05-244.1.

Couto, T.B.A., and Olden, J.D. 2018. Global proliferation of small hydropower plants - science and policy. Front. Ecol. Environ. 16(2): 91-100. doi:10.1002/ fee.1746.

Dibble, K.L., Yackulic, C.B., Kennedy, T.A., and Budy, P. 2015. Flow management and fish density regulate salmonid recruitment and adult size in tailwaters across western North America. Ecol. Appl. 25(8): 2168-2179. doi:10.1890/14-2211.1. PMID:26910947.

DFO. 2012. Long-term monitoring protocols for new and upgraded hydroelectric projects in British Columbia and Yukon Territory. DFO Can. Sci. Advis. Sec. Sci. Advis. Rep. 2011/086.
Dunham, J.B., and Vinyard, G.L. 1997. Relationships between body mass, population density, and the self-thinning rule in stream-living salmonids. Can. J. Fish. Aquat. Sci. 54(5): 1025-1030. doi:10.1139/f97-012.

ESRI Inc. 2020. ArcMap Software (version 10.7.1). Redlands, Calif. Available from https://www.esri.com/en-ca/store/arcgis-desktop.

Ford, B.S., Higgins, P.S., Lewis, A.F., Copper, K.L., Watson, T.A., Gee, C.M., et al. 1995. Literature reviews of the life history, habitat requirements and mitigation/compensation strategies for thirteen sport fish species in the Peace, Liard and Columbia River drainages of British Columbia. Canadian Manuscript Report of Fisheries and Aquatic Sciences 2321. 342 pp.

Gao, Y., Vogel, R.M., Kroll, C.N., LeRoy Poff, N., and Olden, J.D. 2009. Development of representative indicators of hydrologic alteration. J. Hydrol. 374: 136-147. doi:10.1016/j.jhydrol.2009.06.009.

Gibeau, P., Connors, B.M., and Palen, W.J. 2017. Run-of-River hydropower and salmonids: potential effects and perspectives on future research. Can. J. Fish. Aquat. Sci. 74(7): 1135-1149. doi:10.1139/cjfas-2016-0253.

Gouraud, V., Capra, H., Sabaton, C., Tissot, L., Lim, P., Vandewalle, F., et al. 2008. Long-term simulations of the dynamics of trout populations on river reaches bypassed by hydroelectric installations - analysis of the impact of different hydrological scenarios. River Res. Appl. 24(9): 1185-1205. doi:10.1002/rra.1129.

Greenblatt, J.B., Brown, N.R., Slaybaugh, R., Wilks, T., Stewart, E., and McCoy, S.T. 2017. The future of low carbon electricity. Annu. Rev. Environ. Resour. 42: 289316. doi:10.1146/annurev-environ-102016-061138.

Grueber, C.E., Nakagawa, S., Laws, R.J., and Jamieson, I.G. 2011. Multimodel inference in ecology and evolution: challenges and solution. J. Evol. Biol. 24(4): 699-711. doi:10.1111/j.1420-9101.2010.02210.x. PMID:21272107.

Habit, E., Belk, M., and Parra, O. 2007. Response of the riverine fish community to the construction and operation of a diversion hydropower plant in Central Chile. Aquat. Conserv. Mar. Freshw. Ecosyst. 17(1): 37-49. doi:10.1002/aqc.774.

Harvey, B.C., Nakamoto, R.J., and White, J.L. 2006. Reduced streamflow lowers dry-season growth of rainbow trout in a small stream. Trans. Am. Fish. Soc. 135: 998-1005. doi:10.1577/T05-233.1.

Hatfield, T., and Bruce, J. 2000. Predicting salmonid habitat-flow relationships for streams from Western North America. N. Am. J. Fish. Manage. 20(4): 1005-1015. doi:10.1577/1548-8675(2000)020<1005:PSHFRF > 2.0.CO;2.

Hatfield, T., Lewis, A., and Babakaiff, S. 2007. Guidelines for the collection and analysis of fish and fish habitat data for the purpose of assessing impacts from small hydropower projects in British Columbia. British Columbia Ministry of Environment. Victoria, BC.

Heggenes, J. 1988. Effects of short-term flow fluctuations on displacement of, and habitat use by, brown trout in a small stream. Trans. Am. Fish. Soc. 117(4): 336-344. doi:10.1577/1548-8659(1988)117<0336:EOSFFO>2.3.CO;2.

Heggenes, J., Alfredsen, K., Bustos, A.A., Huusko, A., and Stickler, M. 2018. Be cool: a review of hydro-physical changes and fish responses in winter in hydropower-regulated northern streams. Environ. Biol. Fish. 101(1): 1-21. doi:10.1007/s10641-017-0677-z.

Irvine, J.R. 1986. Effects of varying discharge on the downstream movement of salmon fry, Oncorhynchus tschawytscha Walbaum. J. Fish Biol. 28(1): 17-28. doi:10.1111/j.1095-8649.1986.tb05137.x.

Jenkins, T., Jr., Elliott, G., and Feldmeth, C. 1970. Feeding of rainbow trout (Salmo gairdneri) in relation to abundance of drifting invertebrates in a mountain stream. J. Fish. Res. Bd. Can. 27(12): 2356-2361. doi:10.1139/f70264.

Jesus, T., Formigo, N., Santos, P., and Tavares, G.R. 2004. Impact evaluation of the Vila Vicosa small hydroelectric power plant (Portugal) on the water quality and on the dynamics of the benthic macroinvertebrate communities of the Ardena River. Limnetica, 23(3-4): 241-255.

Jowett, I.G., and Biggs, B.J. 2006. Flow regime requirements and the biological effectiveness of habitat-based minimum flow assessments for six rivers. Int. J. River Basin Manag. 4(3): 179-189. doi:10.1080/15715124.2006.9635287.

Korman, J., Walters, C., Martell, S.J.D., Pine, W.E., III, and Dutterer, A. 2011. Effects of flow fluctuations on habitat use and survival of age- 0 rainbow trout (Oncorhunchus mykiss) in a large, regulated river. Can. J. Fish. Aquat. Sci. 68(6): 1097-1109. doi:10.1139/f2011-045.

Kubečka, J., Matěna, J., and Hartvich, P. 1997. Adverse ecological effects of small hydropower stations in Czech Republic: 1. Bypass Plants. Regul. Rivers Res. Mgmt. 13(2): 101-113. doi:10.1002/(SICI)1099-1646(199703)13:2<101::AIDRRR439>3.0.CO;2-U.

Laliberte, J.J., Post, J.R., Rosenfeld, J.S., and Mee, J.A. 2014. Hydraulic geometry and longitudinal patterns of habitat quantity and quality for rainbow trout (Oncorhynchus mykiss). River Res. Appl. 30(5): 593-601. doi:10.1002/ rra.2666.

Laliberte, J.J., Post, J.R., Rosenfeld, J.S., and Mee, J.A. 2016. Modelling temperature, body size, prey density, and stream gradient impacts on longitudinal patterns of potential production of drift-feeding trout. River Res. Appl. 32(10): 2045-2055. doi:10.1002/rra.3048.

LWBC. 2005. Hydrological guidelines for waterpower projects. Land and Water British Columbia Inc. (LWBC), Surrey Regional Office, Land and Water Management Division.

Lewis, A., Hatfield, T., Chilibeck, B., and Roberts, C. 2004. Assessment methods for aquatic habitat and instream flow characteristics in support of applications to dam, divert, or extract water from streams in British Columbia. Report prepared for the Ministry of Water, Land and Air Protection and the Ministry of Sustainable Resource Management. 
Lewis, F.J.A., Harwood, A.J., Zyla, C., Ganshorn, K.D., and Hatfield, T. 2013. Long-term aquatic monitoring protocols for new and upgraded hydroelectric projects. DFO Can. Sci. Adv. Secretariat Res. Doc. 2012/166(ix)+-88p.

Ligon, F.K., Dietrich, W.E., and Trush, W.J. 1995. Downstream ecological effects of dams. Bioscience, 45(3): 183-192. doi:10.2307/1312557.

Lobón-Cerviá, J. 2008. Habitat quantity enhances spatial variation in the self-thinning patterns of stream-resident brown trout (Salmo trutta). Can. J. Fish. Aquat. Sci. 65(9): 2006-2015. doi:10.1139/F08-105.

McGrath, K.E., Scott, J.M., and Rieman, B.E. 2008. Length variation in Age-0 Westslope Cutthroat Trout at multiple spatial scales. N. Am. J. Fish. Manage. 28(5): 1529-1540. doi:10.1577/M07-120.1.

Murchie, K.J., Hair, K.P.E., Pullen, C.E., Redpath, T.D., Stephens, H.R., and Cooke, S.J. 2008. Fish response to modified flow regimes in regulated rivers: research methods, effects and opportunities. River Res. Appl. 24(2): 197-217. doi:10.1002/rra.1058.

Nakamura, T. 2013. Effects of flow reduction on a Whitespotted Char population in a Japanese mountain stream. N. Am. J. Fish. Manage. 33(6): 1142-1148. doi:10.1080/02755947.2013.826757.

Naman, S.M., Rosenfeld, J.S., Third, L.C., and Richardson, J.S. 2017. Habitatspecific production of aquatic and terrestrial invertebrate drift in small forest streams: implications for drift-feeding fish. Can. J. Fish. Aquat. Sci. 74(8): 1208-1217. doi:10.1139/cjfas-2016-0406.

Nehring, R.B., and Anderson, R.M. 1993. Determination of population-limiting critical salmonid habitats in Colorado streams using the Physical Habitat Simulation System. Rivers, 4(1): 1-19.

Nilsson, C., Reidy, C.A., Dynesius, M., and Revenga, C. 2005. Fragmentation and flow regulation of the world's large river systems. Science, 308(5720): 405-408. doi:10.1126/science.1107887. PMID:15831757.

Nislow, K.H., and Armstrong, J.D. 2012. Towards a life-history-based management framework for the effects of flow on juvenile salmonids in streams and rivers. Fish. Manag. Ecol. 19(6): 451-463. doi:10.1111/j.1365-2400.2011. 00810.x.

Nyström, P., McIntosh, A.R., and Winterbourn, M.J. 2003. Top-down and bottomup processes in grassland and forested streams. Oecologia, 136(4): 596-608. doi:10.1007/s00442-003-1297-1. PMID:12802674.

Ovidio, M., Capra, H., and Philippart, J.-C. 2008. Regulated discharge produces substantial demographic changes on four typical fish species of a small salmonid stream. Hydrobiologia, 609: 59-70. doi:10.1007/s10750008-9399-8.

Parkinson, E.A., Lea, E.V., Nelitz, M.A., Knudson, J.M., and Moore, R.D. 2016. Identifying temperature thresholds associated with fish community changes in British Columbia, Canada, to support identification of temperature sensitive streams. River Res. Appl. 32(3): 330-347. doi:10.1002/ rra.2867.

Poff, N.L., Allan, D.J., Bain, M.B., Karr, J.R., Prestegaard, K.L., Richter, B.D., et al. 1997. The natural flow regime. BioScience, 47(11): 769-784. doi:10.2307| 1313099.

Poff, N.L., and Zimmerman, J.K.H. 2010. Ecological responses to altered flow regimes: a literature review to inform the science and management of environmental flows. Freshw. Biol. 55(1): 194-205. doi:10.1111/j.1365-2427.2009. 02272.x.

Power, M.E. 1995. Floods, food chains, and ecosystem processes in rivers. In Linking Species \& Ecosystems. Edited by C.G. Jones and J.H. Lawton. Springer, Boston, Mass. pp. 52-60.

Ptolemy, R.A. 2005. Biomass benchmarks for coastal cutthroat trout (Oncorhynchus clarki clarki): Can ecoregions be used as a place-based standard for abundance? In Proceedings of the Coastal Cutthroat Trout Symposium: Biology, Status, Management, and Conservation, Fort Worden State Park, 29 September1 October, 2005. Edited by P.J. Connolly, T.H. Williams, and R.E. Gresswell
Quadroni, S., Crosa, G., Gentili, G., and Espa, P. 2017. Response of stream benthic macroinvertebrates to current water management in Alpine catchments massively developed for hydropower. Sci. Total Environ. 609: 484-496. doi:10.1016/j.scitotenv.2017.07.099. PMID:28755598.

$\mathrm{R}$ Core Team. 2016. R: A language and environment for statistical computing. R Foundation for Statistical Computing, Vienna, Austria. Available from https://www.R-project.org.

Railsback, S.F., and Rose, K.A. 1999. Bioenergetics modeling of stream trout growth: temperature and food consumption effects. Trans. Am. Fish. Soc. 128(2): 241-256. doi:10.1577/1548-8659(1999)128<0241:BMOSTG > 2.0.CO;2.

Rosenberg, D.M., Berkes, F., Bodaly, R.A., Hecky, R.E., Kelly, C.A., and Rudd, J.W.M. 1997. Large-scale impacts of hydroelectric development. Environ. Rev. 5(1): 27-54. doi:10.1139/a97-001.

Rosenfeld, J., Beecher, H., and Ptolemy, R. 2016. Developing bioenergeticbased habitat suitability curves for instream flow models. N. Am. J. Fish. Manage. 36(5): 1205-1219. doi:10.1080/02755947.2016.1198285.

Rosenfeld, J.S. 2014. Modelling the effects of habitat on self-thinning, energy equivalence, and optimal habitat structure for juvenile trout. Can. J. Fish. Aquat. Sci. 71(9): 1395-1406. doi:10.1139/cjfas-2013-0603.

Rosenfeld, J.S. 2017. Developing flow-ecology relationships: implications of nonlinear biological responses for water management. Freshw. Biol. 62(8): 1305-1324. doi:10.1111/fwb.12948.

Sabaton, C., Souchon, Y., Capra, H., Gouraud, V., Lascaux, J.-M., and Tissot, L. 2008. Long-term brown trout populations responses to flow manipulation. River Res. Appl. 24(5): 476-505. doi:10.1002/rra.1130.

Shelton, J.M., Samways, M.J., and Day, J.A. 2015. Non-native rainbow trout change the structure of benthic communities in headwater streams of the Cape Floristic Region, South Africa. Hydrobiologia, 745(1): 1-15. doi:10.1007| s10750-014-2067-2.

Sims, R.E.H., Rogner, H.H., and Gregory, K. 2003. Carbon emissions and mitigation cost comparisons between fossil fuel, nuclear and renewable energy resources for electricity generation. Energy Policy, 31(13): 13151326. doi:10.1016/S0301-4215(02)00192-1.

Smith, B.D. 2000. Trends in wild adult steelhead (Oncorhynchus mykiss) abundance for snowmelt-driven watersheds of British Columbia in relation to freshwater discharge. Can. J. Fish. Aquat. Sci. 57(2): 285-297. doi:10.1139/ f99-255.

SECL. 2011. Cloudworks Energy Inc. Long-term Monitoring Program: (LTMP) Kwalsa and Stave Area Plants: Invertebrate Abundance 2010 Monitoring Results. Prepared for Cloudworks Energy Inc. Streamline Environmental Consulting Ltd.

Tissot, L., Bret, V., Capra, H., Baran, P., and Gouraud, V. 2017. Main potential drivers of trout population dynamics in bypassed stream sections. Ecol. Freshw. Fish. 26(3): 336-346. doi:10.1111/eff.12295.

Turner, D., Bradford, M.J., Venditti, J.G., and Peterman, R.M. 2016. Evaluating uncertainty in physical habitat modelling in a high-gradient mountain stream. River Res. Appl. 32(5): 1106-1115. doi:10.1002/rra.2915.

Van Deventer, J.S. 2006. MicroFish 3.0 Demonstration Version. Available from www.microfish.org.

Wills, T.C., Baker, E.A., Nuhfer, A.J., and Zorn, T.G. 2006. Response of the benthic macroinvertebrate community in a northern Michigan stream to reduced summer streamflows. River Res. Appl. 22(7): 819-836. doi:10.1002/ rra.938.

Wu, N., Tang, T., Zhou, S., Jia, X., Li, D., Liu, R., and Cai, Q. 2009. Changes in benthic algal communities following construction of a run-of-river dam. J. N. Am. Benthol. Soc. 28(1): 69-79. doi:10.1899/08-047.1.

Zuur, A.F., Ieno, E.N., and Elphick, C.S. 2010. A protocol for data exploration to avoid common statistical problems. Methods Ecol. Evol. 1(1): 3-14. doi:10.1111/j.2041-210X.2009.00001.x. 